\title{
Later stages of evolution of an epithermal system: Au-Ag mineralizations at Apigania Bay, Tinos Island, Cyclades, Hellas, Greece
}

\author{
S. F. Tombros • K. St. Seymour • \\ A. E. Williams-Jones $\cdot$ P. G. Spry
}

Received: 31 March 2007 / Accepted: 12 July 2008 /Published online: 4 September 2008

(C) The Author(s) 2008. This article is published with open access at Springerlink.com

\begin{abstract}
Precious metals accompany all types of epithermal deposits. In general, the largest of these deposits occur in intrusive or extrusive rocks of alkaline or calc-alkaline affinity. The Apigania Bay vein system and $\mathrm{Au}-\mathrm{Ag}$ mineralization is hosted in Mesozoic marbles and schists, and is composed primarily of five nearly parallel, high-angle quartz veins that extend for at least $200 \mathrm{~m}$. Gold-silver mineralization, in association with more than thirty ore and vein minerals, is developed in three stages and occurs at the contact of marbles and schists. Zones of epidote-chlorite-calcite and sericite-albite alteration are associated with precious metal-bearing milky and clear quartz veins. Fluid inclusion studies suggest that hydrothermal mineralization was deposited under hydrostatic pressures of $\sim 100$ bars, at temperature
\end{abstract}

Editorial handling: R. Abart

S. F. Tombros $(\bowtie) \cdot K$. St. Seymour

Department of Geology, University of Patras,

Hellas, Greece

e-mail: tompros@mailbox.gr

K. St. Seymour

e-mail: kstseymr@upatras.gr

K. St. Seymour

Department of Chemistry and Geography, Concordia University,

Montreal, QC, Canada

A. E. Williams-Jones

Department of Earth and Planetary Sciences,

3450, University Street,

Montreal, QC H3A 2A7, Canada

e-mail: willyj@eps.mcgill.ca

P. G. Spry

Department of Geological and Atmospheric Sciences,

Iowa State University,

253 Science I,

Ames, IA 50011, USA

e-mail: pgspry@iastate.edu of $120-235^{\circ} \mathrm{C}$, from low to moderate, calcium-bearing, saline fluids of 0.2 to 6.8 equiv. wt.\% $\mathrm{NaCl}$. Calculated isotope compositions $\left(\delta^{18} \mathrm{O}=-4.7 \%\right.$ to $1.7 \%$ and $\delta \mathrm{D}=$ $-120 \%$ to $-80 \%$ ) for waters in equilibrium with milky and clear quartz are consistent with mixing with dilute, low temperature meteoric ore fluids. Calculated $\delta^{13} \mathrm{C}_{\mathrm{CO} 2}(0.6 \%$ to $1.1 \%$ ) and $\delta^{34} \mathrm{~S}_{\mathrm{H} 2 \mathrm{~S}}(-7.3$ to $-0.3 \%$ ) compositions of the ore fluids indicate exchange, in an open system, with a metasedimentary source. Gold and silver deposition was associated with degassing of hydrogen due to intense uplift of the mineralizing area. The physicochemical conditions of mineralization stages I to III range between $200^{\circ} \mathrm{C}$ and $150^{\circ} \mathrm{C}, f_{\mathrm{S}_{2}}=10^{-18.1}$ to $10^{-16.8}, f_{\mathrm{O}_{2}}=10^{-44.0}$ to $10^{-41.5}, \mathrm{pH}=6.9$ to $7.6, f_{\mathrm{H}_{2} \mathrm{~S}}=10^{-3.4}$ to $10^{-2.6}$ and $a_{\mathrm{H}_{2} \mathrm{~S}}=$ $10^{-2.7}$ to $10^{-2.6}$. Apigania Bay could be possibly considered the latest evolutional phase of Tinos hydrothermal system.

\section{Introduction}

Reviews of $\mathrm{Au}-\mathrm{Ag} \pm \mathrm{Te}$ deposits in Hellas (Greece) reveal that they are hosted within Oligocene to Miocene magmatic systems as epithermal and/or porphyry occurrences in two areas: the Northeastern Hellenic and the Cyclades belts. In the northeastern Hellenic belt the Servomacedonian-Rhodope metallogenic area hosts several major ore deposits (Skarpelis et al. 1999), i.e., replacement style massive $\mathrm{Zn}-\mathrm{Pb}-\mathrm{Au}-\mathrm{Ag}$ deposit at Olympias, Chalkidiki ( $120 \mathrm{~g} / \mathrm{t} \mathrm{Ag}$ and $5.5 \mathrm{~g} / \mathrm{t} \mathrm{Au}$ ); Madam Lakkos and Mavres Petres $(110 \mathrm{~g} / \mathrm{t} \mathrm{Ag}$ and $1.5 \mathrm{~g} / \mathrm{t}$ $\mathrm{Au}$; Kalogeropoulos et al. 1989; Nebel et al. 1991; Kilias et al. 1996), porphyry $\mathrm{Cu}-\mathrm{Au}$ at Skouries, Chalkidiki (0.9 g/t $\mathrm{Au}, 2.5 \mathrm{~g} / \mathrm{t} \mathrm{Pd}$ and $0.6 \% \mathrm{Cu}$ ), epithermal $\mathrm{Au}-\mathrm{Ag}-\mathrm{Te}$ at St. Demetrios, Fakos and Perama Hill, Thrace (3.5 to $3.7 \mathrm{~g} / \mathrm{t}$ $\mathrm{Au}$; Voudouris and Alfieris 2004; Voudouris 2006), and epithermal to porphyry at St. Barbara, Mavrokoryfi and Pefka, Thrace (Voudouris et al. 2006). 
Gold-silver mineralization at Apigania Bay, Tinos Island, Hellas (Greece) was first recognized by Melidonis (1980), and subsequently remapped by Tombros (2001). It occurs in a stockwork of early milky and late clear quartz veins in Triassic marbles and schists. Previous studies of the Apigania Bay ores are limited and have focused on the temperature of ore formation (Tombros and St. Seymour 1998) and the reasons for the presence of cassiterite in the mineralization (Tombros and St. Seymour 2003). This study investigates the mineralogical, paragenetic, fluid inclusion, stable isotope (i.e., sulfur, carbon, oxygen, and hydrogen), geochemical characteristics, which have been conducted to constrain the thermochemical conditions of ore formation, and its potential genetical link to the Miocene fluorine- and boron-bearing Tinos leucogranite (Tombros 2001). Epithermal gold mineralization at Apigania Bay is one of several granite-related gold-silver occurrences in Hellas (Greece); as recent investigations include the mineralizations situated at the foot- and hanging-walls of several shear zones all over the Attico-Cycladic Massif (i.e., Lavrion, Mykonos, Paros, Naxos and Ikaria).

\section{Regional geological setting}

The Attico-Cycladic belt (ABC) is one of the most spectacular Alpine orogenic belts and is considered to mark the location of an ancient convergence zone (Blake et al. 1981). On Tinos Island, Hellas (Greece), this belt is essentially composed of a package of Alpine nappes (Fig. 1a,b). The so-called Basal unit (Fig. 1a,b) is composed of LateTriassic to Late-Cretaceous platform of neritic limestones, overlain by Paleocene flysch (Melidonis 1980; Boronkay and Doutsos 1994). The "Blueschist unit" was initially a Mesozoic continental margin of neritic sediments and basic to acid volcanic rocks (Fig. 1a,b; Parra et al. 2002). Highpressure, low-temperature blueschist facies metamorphism occurred during the Eocene-Miocene and was accompanied by a Barrovian overprint, which formed during exhumation of the high-pressure rocks during the Oligocene-Miocene (Avigad and Garfunkel 1989, 1991; Bröcker 1990; Bröcker et al. 1993). The Blueschist unit was overthrust by ophiolites of the "Upper unit", which was metamorphosed to the greenschist facies (Okrusch and Bröcker 1990; Katzir et al. 1996; Patzak et al. 1994; Bröcker and Enders 1999; Pulitz et al. 2000). The extensional detachment separating the Upper from the Blueschist unit was pierced by a Miocene granodioriteleucogranite (Altherr and Siebel 2002). Granodiorite have intruded along syn-magmatic ductile faults (Boronkay 1995; Mastrakas and St. Seymour 2000; Zeffren et al. 2005), while its contact with the country rocks served as a conduit for a boron- and fluorine-rich leucogranite, which formed peripherally to the granodiorite (Mastrakas 2007). The Tinos granodiorite was emplaced during the Mid- to Late-Miocene in a transpressional regime (Mastrakas and St. Seymour 2000; Bröcker et al. 2004), and subsequently deformed under ductile to brittle conditions in a Late Miocene to Pliocene transtensional setting (Boronkay and Doutsos 1994; Mastrakas and St. Seymour 2000). K-Ar ages of ca. 18 to $15 \mathrm{Ma}$ were obtained for the Tinos granodiorite (from amphibole and biotite separates, Altherr et al. 1982). The leucogranite was emplaced under transtension (Mastrakas and St. Seymour 2000) and has been dated at $14 \pm 0.1 \mathrm{Ma}$ (whole rock $\mathrm{Rb}-\mathrm{Sr}$ isochrons from titanite and apatite, Altherr et al. 1982; Henjes-Kunst and Kreuzer 1982). The pluton caused contact metamorphism and formation of scheelite mineralization (Melidonis 1980; Mastrakas 2007). Rb-Sr ages from biotite suggest that the contact aureole formation was at $\sim 14 \mathrm{Ma}$ (Bröcker and Franz 2000). The width of the contact aureole ranges from 600 to 2,000 m (Bröcker and Franz 1994, 1998; Mastrakas 2007). The inner zone ( $\approx 1 \mathrm{~km}$ wide) consists of pyroxene and amphibole hornfelses, pyroxene-garnet skarns and marbles, whereas the outer zone is composed of albite-epidote hornfelses (Stolz et al. 1997). NE- and NWtrending aplitic dikes and veins intrude the pluton and country rocks (Mastrakas and St. Seymour 2000). A swarm of NWtrending Miocene ryolitic dikes (with $\mathrm{K}-\mathrm{Ar}$ ages of $11.5 \mathrm{Ma}$, Avigad et al. 1994) and tiny outcrops of Miocene-Pliocene clastic sediments complete Tinos tectono-stratigraphy.

\section{The Apigania Bay vein system}

The Apigania Bay vein system is hosted in marbles and schists of the Blueschist unit (Fig. 2; Tombros 2001). Thin- to thick-bedded muscovite-chlorite-stilpomelane-biotite-glaucophane marbles are intercalated with blueschists, greenschists and amphibolites and represent the Blueschist unit base, whereas intercalations of blueschists, greenschists, marbles, and ultramafics occur on the top. The greenschists, in the area, are dominated by the assemblage of quartz-calcitemuscovite-chlorite-actinolite-epidote-biotite-titanitetourmaline-albite are mineralized with pyrite, Co-bearing pentlandite, pyrrhotite and magnetite (Melidonis 1980).

The Apigania vein system consists of five high-angle quartz veins "tension gashes" that extend vertically for at least $200 \mathrm{~m}$, filling a conjugate system of NE-trending sinistral and NW dextral strike-slip faults (Tombros and St. Seymour 1998; Tombros 2001). Blueschist unit marbles and schists are intruded by two generations of syntaxial veins: an older, northeasterly trending milky set of quartz veins and a younger group of northwesterly trending clear quartz veins (Fig. 2). The two vein systems form a stockwork, in which milky quartz veins, up to $2 \mathrm{~m}$ wide, contain minor amounts of pyrite, sphalerite, tetrahedrite and chalcopyrite, whereas the clear quartz veins (up to $2 \mathrm{~m}$ wide) display well-developed comb textures, and contain up to $20 \mathrm{vol} . \%$ galena. 
Fig. 1 Map showing: a generalized geology and $\mathbf{b}$ tectonic domain of Tinos Island and the location of the Apigania and

Panormos Bay $\mathrm{Au}-\mathrm{Ag}-\mathrm{Te}$ mineralization (modified after

Melidonis 1980; Mastrakas and Seymour 2000; Skarpelis 2001, and Landsat-Tm, Spot-PAN, and DEM satellite images)

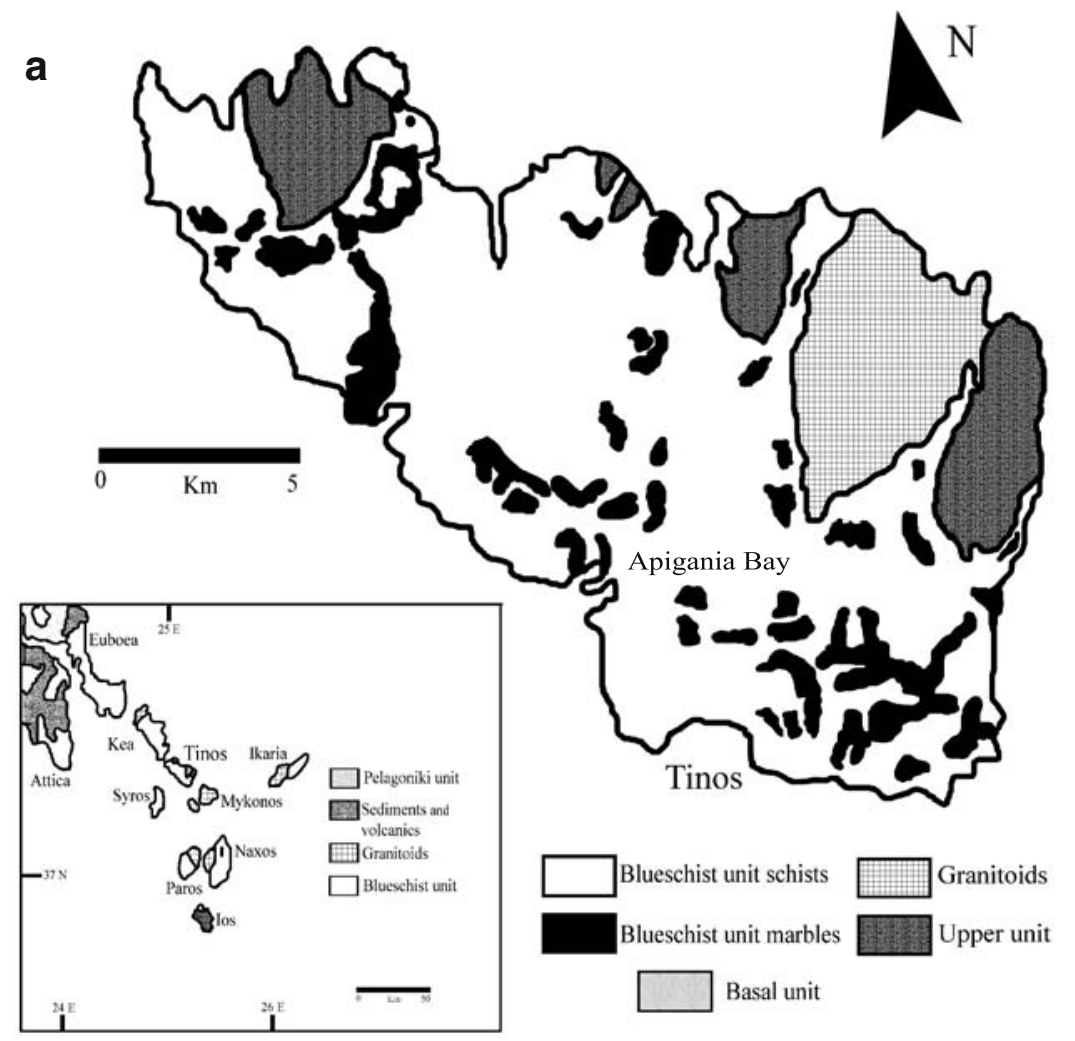

b

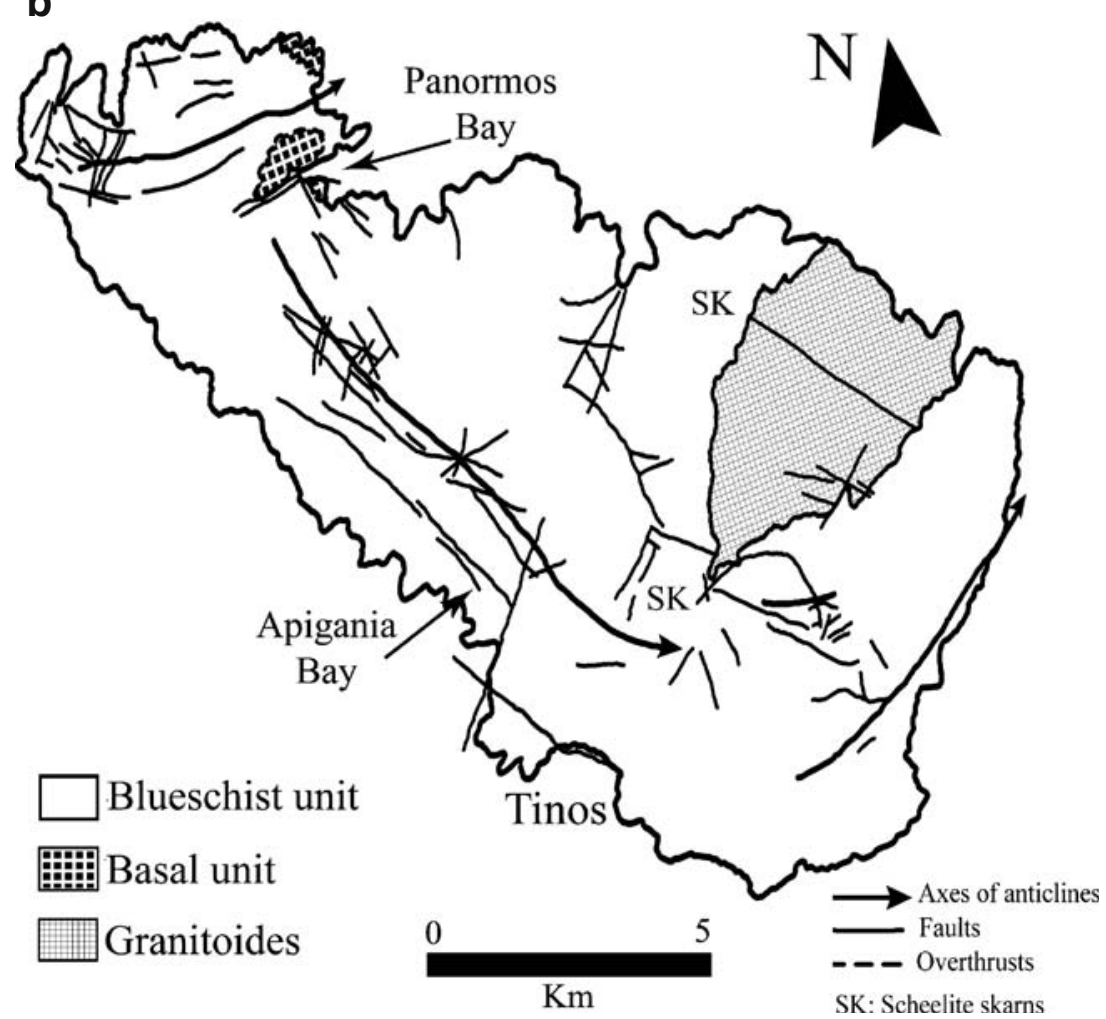


Fig. 2 Location, and geological map and cross section of Apigania Bay vein system, showing the distribution of the milky and clear quartz veins and the Au-Ag mineralization (after Tombros 2001). Apigania Bay vein system is shown at the upper map and a cross section of a banded vein in the lower part, respectively. In Apigania Bay vein system there is a set of NE-trending banded mineralized veins filled with milky quartz (veins $A_{2}, A_{3}, A_{5}$ ) with band $\mathrm{A}$ (outer) and band $\mathrm{B}$ (inner) of the veins. The second group comprises NW-trending banded mineralized veins with clear quartz $\left(A_{1}, A_{4}\right)$ and band $\mathrm{C}$ (outer) and $\mathrm{D}$ (inner). $A_{1}-A_{5}$ represents the major metalliferous veins in the area
Ores

Alteration zones (Epidote-Chlorite)

Schists of Blueschist unit

Marbles of Blueschist unit

Clear quartz

Milky quartz

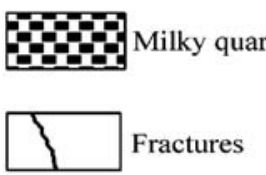

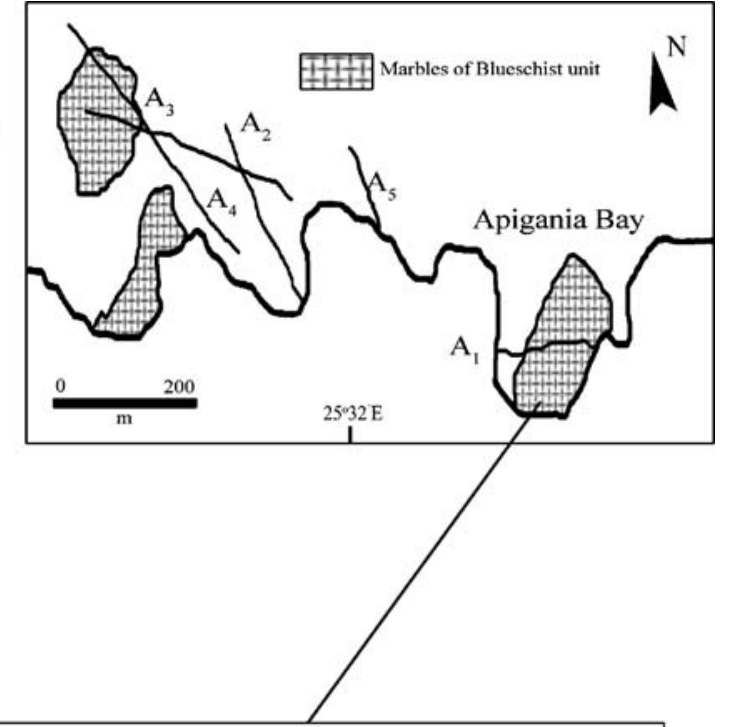

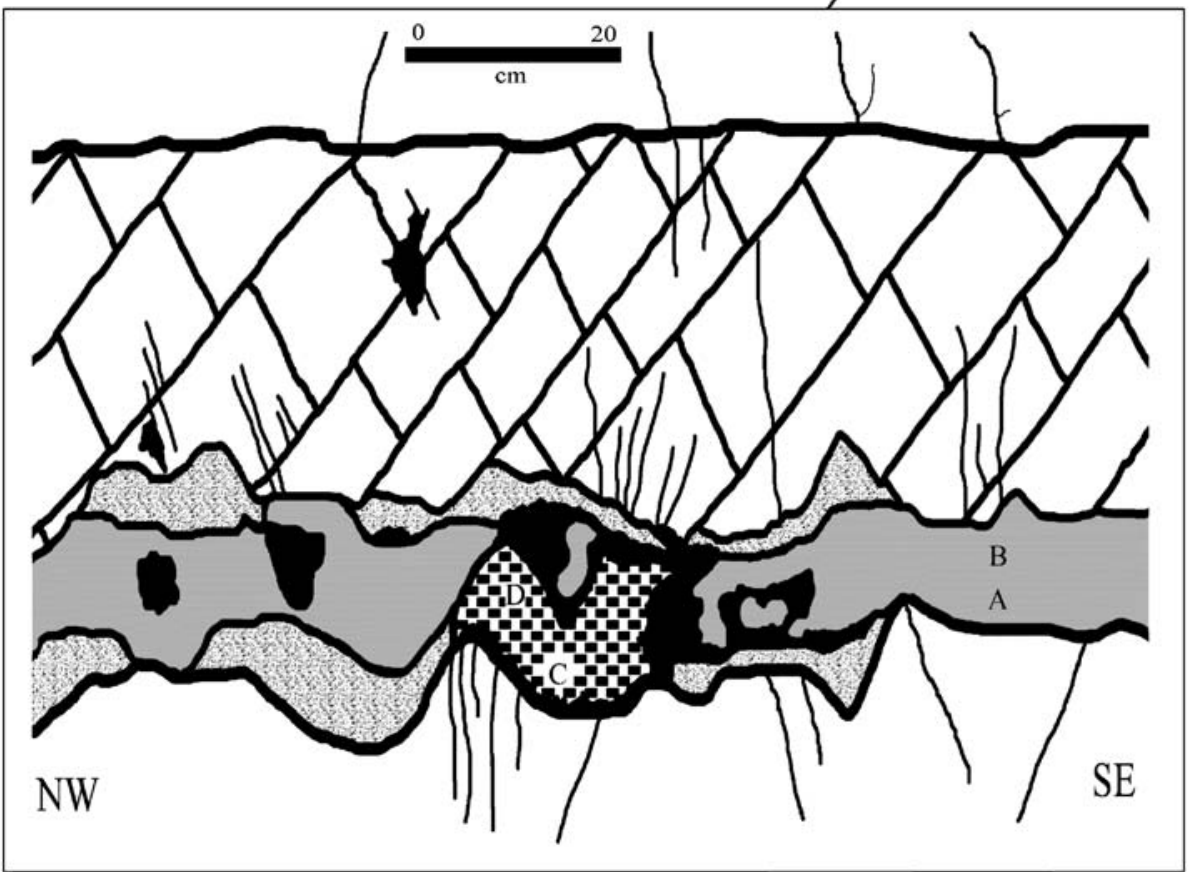

Crustification is apparent in quartz veins which are $\geq 10 \mathrm{~cm}$ wide. Four different bands (with widths up to $50 \mathrm{~cm}$; referred to here as, type A to D) have been classified, giving a generalized sequence of: (1) fine-grained milky quartz ( $>70$ vol.\%) with abundant fragments of marble and schist (Type A), (2) medium-grained milky quartz ( $\approx 50 \mathrm{vol}$. $\%$ ), epidote ( $\approx 30$ vol.\%), albite, sericite (both 10 vol.\%), ankerite $(\approx 5$ vol. $\%$ ), with pyrite and sphalerite (both 5 vol. $\%$ ) (type B), (3) fine-grained clear quartz ( $<60$ vol.\%) with calcite $(\approx 30$ vol. $\%$ ) and chlorite (type $C)$, and (iv) mediumto coarse-grained clear quartz in dogtooth comb textures ( $<70$ vol. $\%$ ), calcite ( $<20$ vol. $\%$ ), and chlorite (type D). In a single vein (i.e., vein $\mathrm{A}_{1}$, Fig. 2) bands $\mathrm{A}$ and $\mathrm{B}$ with convolute morphologies are mainly developed in the outer parts of the vein, in a NE direction (Fig. 3a). NW-trending discontinuous $\mathrm{C}$ and $\mathrm{D}$ bands cross-cut the former and occupy the central parts of the veins (Fig. 3a). Milky quartz crystals with mottled extinction patterns are symmetrically banded, clear quartz crystals terminate within open cavities, whereas calcite crystals appears bladed (Fig. 3a).

\section{Analytical methods}

Mineral compositions from the Apigania Bay vein system were determined with a Joel 8900 Superprobe, equipped with wave and energy dispersive and back-scattered detector at Microprobe Center of the Department of Earth and Planetary Sciences Department, at McGill University. Operating conditions were an acceleration voltage of $15 \mathrm{kV}$, a beam 

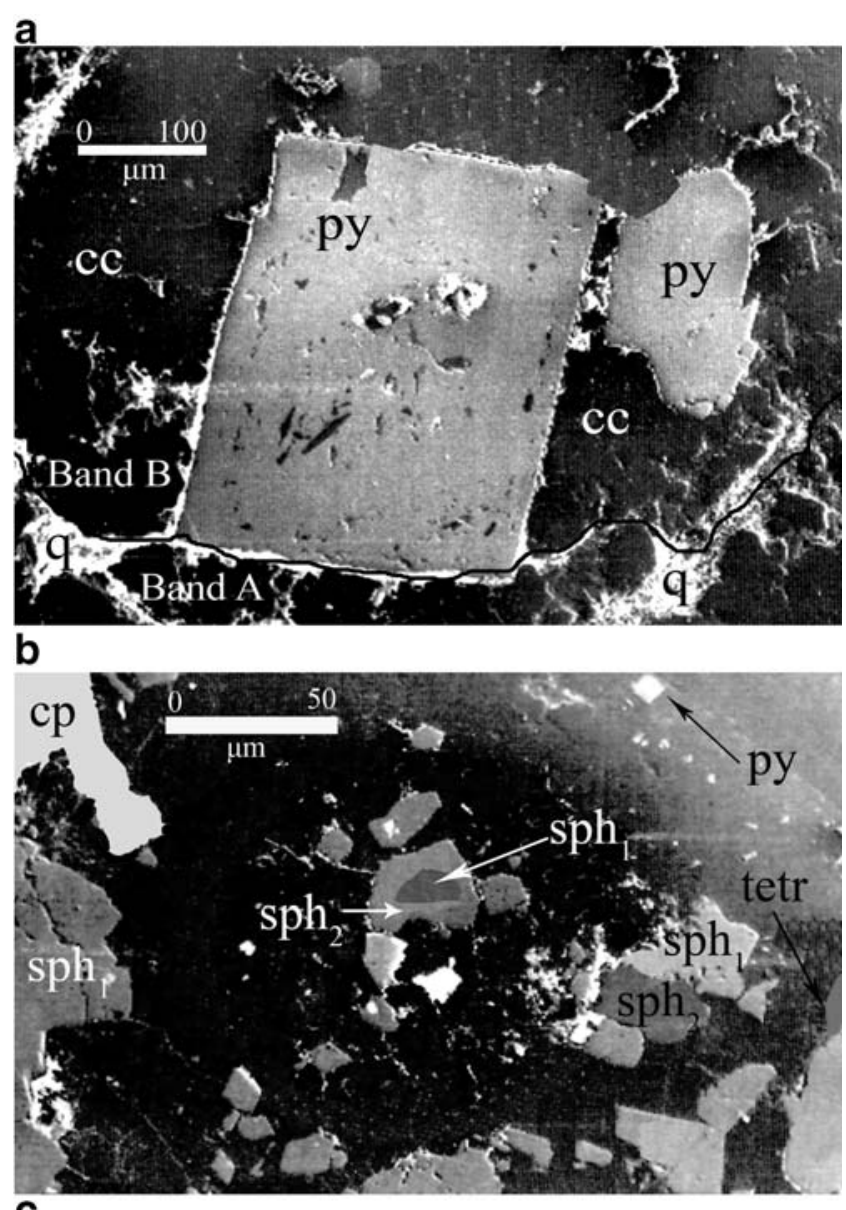

C

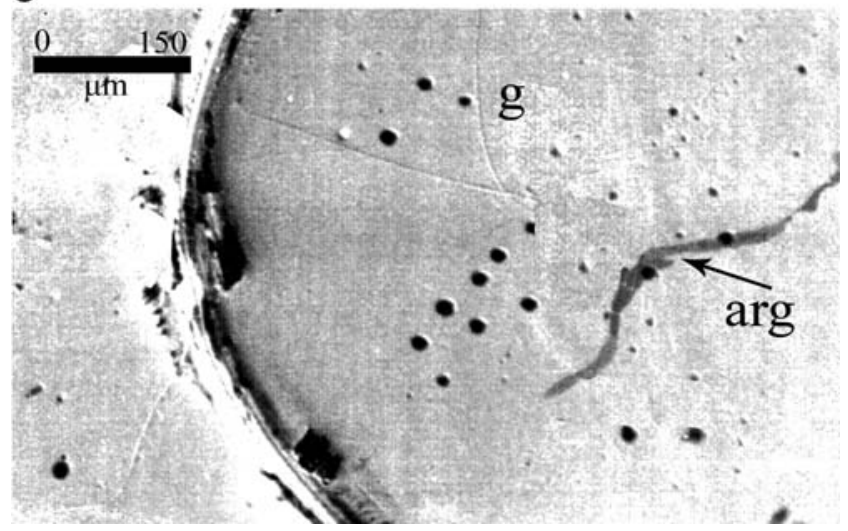

Fig. 3 Back-scattered electron images of: a stage I pyrite ( $p y)$ developed in the transitional zone of bands $\mathrm{A}$ and $\mathrm{B}$ in milky quartz $(q)$ and calcite $(c c)($ scale bar $=100 \mu \mathrm{m})$; b stage I $(p y)$ and zoned sphalerite (sphalerite cores: $s p h_{1}$ and sphalerite rims: $s p h_{2}$ ) replaced by stage II chalcopyrite $(c p)$ and tetrahedrite $($ tetr $)($ scale bar $=500 \mu \mathrm{m})$; c Stage III galena $(g)$ with argentite-acanthite inclusions ( $\mathrm{arg}$ ) (scale bar $=150 \mu \mathrm{m})$

current of $10 \mathrm{nA}$ and counting times of $20 \mathrm{~s}$. Standards used for vein minerals, were natural calcite, chlorite, epidote and muscovite, whereas for ore minerals natural chalcopyrite, tetrahedrite, tennantite, pyrite, sphalerite, galena, CoNiAs,
$\mathrm{SnO}_{2}, \mathrm{MnTi}$, and native $\mathrm{Ag}, \mathrm{Sb}, \mathrm{Au}, \mathrm{Se}, \mathrm{Ta}$, and $\mathrm{Cd}$ were utilized. The X-ray lines measured were $\mathrm{Ag} L a, \mathrm{Sb} L a, \mathrm{Cu}$ $K a$, Fe Ko, Au Ma, Mn Ka, Se $L a$, Ta $L a$, Cd $L a$, Te $L a$, and $\mathrm{S} K a$. ZAF corrections were made with proprietary JOEL software. A minimum of ten analyses were obtained from each sample and three from each grain.

Microthermometric determinations were performed on doubly polished wafers $50-100 \mu \mathrm{m}$ thick using a modified USGS stage, in the Laboratory of High Temperature Processes at the Department of Earth and Planetary Science Department of McGill University. Temperatures were measured with an alumel-chromel thermocouple and the readings were calibrated with synthetic inclusions at $-56.6^{\circ} \mathrm{C}$ (triple point of $\mathrm{CO}_{2}$ ), at $0.0^{\circ} \mathrm{C}$ (melting point of ice) and at $+374.1^{\circ} \mathrm{C}$ (critical point of $\mathrm{H}_{2} \mathrm{O}$ ). Measurements are accurate to within $0.2^{\circ} \mathrm{C}$ for temperatures $<31^{\circ} \mathrm{C}$ and to $\pm 0.1^{\circ} \mathrm{C}$ for temperatures $>31^{\circ} \mathrm{C}$. Microthermometric data were reduced using the Flincor software (Brown 1989) employing the equations of Brown and Lamb (1989), and Zhang and Frantz (1990). Results of the fluid inclusion study are listed in Table 4.

Material for stable isotope studies was obtained from vein and alteration minerals, host marbles and schists, and smoky quartz from the Tinos leucogranite (Tombros et al. 2007). All minerals selected were handpicked and checked under a binocular microscope to ensure a purity of $>95 \%$. Isotopic compositions of oxygen, hydrogen and carbon were analyzed with a VGSIRA12 triple collector mass spectrometer and those of sulfur with a VGMM602E double collector mass spectrometer. Analyses were performed at Geochron Laboratory, Massachusetts, USA. Oxygen and hydrogen were released from milky, clear and smoky quartz using the $\mathrm{BrF}_{5}$ extraction technique of Clayton and Mayeda (1963) and Friedman and O'Neil (1977), whereas carbon and oxygen in calcite by using the $\mathrm{CO}_{2}$ treating of Clayton et al. (1972). Sulfur was released as $\mathrm{SO}_{2}$ after the method of Fritz et al. (1974). The isotopic ratios are reported in standard $\delta$ notation per mil relative to SMOW for oxygen and hydrogen, Pee Dee belemnite for carbon, and Cañon Diablo troilite for sulfur. Analytical precision was better than $\pm 0.1 \%$ for $\delta^{18} \mathrm{O}$ and $\delta^{13} \mathrm{C}, \pm 1 \%$ for $\delta \mathrm{D}$, and $\pm 0.2 \%$ for $\delta^{34} \mathrm{~S}$.

Trace element analyses were obtained from Act Labs (Canada). Major element compositions were obtained by Xray fluorescence analysis following the method of Taggart et al. (1987). Trace element compositions were measured by inductively coupled plasma atomic emission spectrometry and inductively coupled plasma mass spectrometry techniques of Meier et al. (1994), whereas Au was analyzed by flame atomic absorption (Hubert and Chao 1985). Trace element data were collected from samples of Tinos leucogranite and aplites, smoky quartz (Tombros et al. 2007), milky and clear vein quartz, from the epidote-chlorite alteration zone, and host marbles-schists of the Blueschist unit. 


\section{Hydrothermal alteration}

Alteration zones were developed even around barren milky and clear quartz veins and are widest around the thickest veins, at vein intersections, along fault planes, and in places where host marbles or schists are tectonically brecciated. Discontinuous borders, concentric shells and linear forms are formed, that are parallel to the veins. Marbles develop alteration assemblages enriched in epidote, whereas in schists contain chlorite and calcite. Alteration haloes consist of two zones: an inner epidote and an outer chlorite zone. Adjacent to type A bands are the epidote zones, up to $15 \mathrm{~cm}$, wide which are spatially associated with finegrained milky quartz. They also contain albite, sericite, ankerite, pyrite and sphalerite. Chlorite zones, with widths up to $10 \mathrm{~cm}$, contain clear quartz, chlorite, calcite, minor albite and sericite, tetrahedrite, chalcopyrite and galena. Representative compositions of vein fill and alteration minerals are given in Table 1.

\section{Ore petrography and chemistry}

Apigania Bay ores contain thirty metallic and gangue minerals, including electrum and silver sulfosalts (Tombros and Seymour 1998, 2003). Three paragenetic stages of epithermal mineralization (I to III) are followed by a supergene stage (IV) (Table 2). Mineral stage I (bands A and $\mathrm{B}$ ) is related to the NE-trending milky quartz veins, while stages II and III to the NW-trending clear quartz ones (bands C and D) (Fig. 3b,c). Representative compositions of $\mathrm{Au}-\mathrm{Ag}$ sulfides and sulfosalts are given in Table 3.

Stage I is associated with type B bands, and comprises with pyrite $(\approx 35$ vol.\%), sphalerite $(\approx 30$ vol. $\%)$, minor pyrrhotite, senopyrite, magnetite, argentite, electrum, stephanite $\left[\mathrm{Ag}_{5} \mathrm{SbS}_{4}\right]$, xanthoconite $\left[\mathrm{Ag}_{3} \mathrm{AsS}_{3}\right]$, proustite $\left[\mathrm{Ag}_{3} \mathrm{AsS}_{3}\right]$ and canfieldite $\left[\mathrm{Ag}_{8} \mathrm{SnS}_{6}\right]$. Pyrite develops at the vein margins in massive aggregates which are granular, and intensely brecciated. It also appears as coarse-grained pyritohedra (up to $15 \mathrm{~mm}$ ) and/or as disseminations in

Table 1 Representative electron microprobe analyses of the vein fill and alteration minerals from Apigania Bay vein system

\begin{tabular}{|c|c|c|c|c|c|c|c|c|c|c|c|c|}
\hline Mineral & 1 & 2 & 3 & 4 & 5 & 6 & 7 & 8 & 9 & 10 & 11 & 12 \\
\hline $\mathrm{SiO}_{2}$ & 36.91 & 39.80 & 49.12 & 46.00 & 66.95 & 64.10 & 28.25 & 30.09 & (b.d.) & (b.d.) & (b.d.) & (b.d.) \\
\hline $\mathrm{Al}_{2} \mathrm{O}_{3}$ & 21.94 & 24.42 & 35.27 & 34.97 & 21.01 & 23.87 & 16.98 & 14.91 & (b.d.) & (b.d.) & (b.d.) & (b.d.) \\
\hline $\mathrm{Fe}_{2} \mathrm{O}_{3}$ & 14.18 & 11.35 & 0.02 & 0.03 & 0.09 & (b.d.) & (b.d.) & (b.d.) & (b.d.) & (b.d.) & (b.d.) & (b.d.) \\
\hline $\mathrm{FeO}$ & (b.d.) & (b.d.) & 1.24 & 3.92 & (b.d.) & (b.d.) & 19.90 & 20.43 & 1.09 & 2.57 & 17.92 & 22.74 \\
\hline $\mathrm{MgO}$ & (b.d.) & 0.03 & 0.80 & 0.69 & (b.d.) & 0.01 & 19.52 & 18.49 & 0.94 & 0.01 & 3.61 & 2.11 \\
\hline $\mathrm{CaO}$ & 23.67 & 23.79 & (b.d.) & 0.08 & 1.31 & 2.06 & 0.08 & 0.15 & 57.96 & 51.23 & 19.38 & 18.90 \\
\hline $\mathrm{MnO}$ & 0.25 & 0.08 & 0.02 & 0.21 & 0.03 & 0.01 & 1.62 & 1.59 & 0.38 & 0.50 & 3.19 & 2.95 \\
\hline $\mathrm{Na}_{2} \mathrm{O}$ & (b.d.) & (b.d.) & 0.92 & 1.25 & 10.59 & 9.05 & 0.01 & (b.d.) & (b.d.) & (b.d.) & (b.d.) & (b.d.) \\
\hline $\mathrm{K}_{2} \mathrm{O}$ & (b.d.) & (b.d.) & 9.24 & 9.98 & 0.02 & (b.d.) & 0.01 & 0.02 & (b.d.) & (b.d.) & (b.d.) & (b.d.) \\
\hline $\mathrm{ZnO}$ & (b.d.) & (b.d.) & (b.d.) & (b.d.) & (b.d.) & (b.d.) & (b.d.) & (b.d.) & 0.58 & (b.d.) & (b.d.) & (b.d.) \\
\hline LOI & 2.92 & 0.33 & 3.04 & 2.45 & 0.00 & 0.75 & 13.50 & 10.78 & 38.94 & 44.71 & 55.35 & 53.13 \\
\hline Total & 99.87 & 99.77 & 99.67 & 99.58 & 99.99 & 99.94 & 99.86 & 99.42 & 99.89 & 99.02 & 99.45 & 99.83 \\
\hline \multicolumn{13}{|c|}{ No. of atoms based on } \\
\hline $\mathrm{Si}$ & 3.01 & 2.93 & 2.57 & 2.10 & 2.95 & 2.89 & 5.75 & 6.05 & 0.00 & 0.00 & 0.00 & 0.00 \\
\hline $\mathrm{Al}$ & 2.11 & 2.35 & 3.90 & 3.83 & 0.98 & 1.15 & 4.00 & 3.50 & 0.00 & 0.00 & 0.00 & 0.00 \\
\hline $\mathrm{Fe}$ & 0.97 & 0.77 & 0.56 & 1.09 & 0.02 & 0.00 & 3.39 & 3.44 & 0.02 & 0.12 & 0.39 & 0.45 \\
\hline $\mathrm{Mg}$ & 0.00 & 0.00 & 0.08 & 0.07 & 0.01 & 0.00 & 5.92 & 5.55 & 0.02 & 0.00 & 0.09 & 0.06 \\
\hline $\mathrm{Ca}$ & 2.07 & 2.08 & 0.00 & 0.00 & 0.1 & 0.12 & 0.02 & 0.03 & 0.95 & 0.87 & 0.45 & 0.43 \\
\hline $\mathrm{Mn}$ & 0.02 & 0.01 & 0.00 & 0.00 & 0.00 & 0.00 & 0.28 & 0.27 & 0.00 & 0.01 & 0.07 & 0.06 \\
\hline $\mathrm{K}$ & 0.00 & 0.00 & 0.78 & 0.77 & 0.00 & 0.00 & 0.00 & 0.01 & 0.00 & 0.00 & 0.00 & 0.00 \\
\hline $\mathrm{Na}$ & 0.00 & 0.00 & 0.12 & 0.16 & 0.99 & 0.92 & 0.00 & 0.00 & 0.00 & 0.00 & 0.00 & 0.00 \\
\hline $\mathrm{Zn}$ & 0.00 & 0.00 & 0.00 & 0.00 & 0.00 & 0.00 & 0.00 & 0.00 & 0.01 & 0.00 & 0.00 & 0.00 \\
\hline $\mathrm{OH}$ & $0.94^{\mathrm{a}}$ & $0.96^{\mathrm{a}}$ & $1.99^{\mathrm{b}}$ & $1.98^{\mathrm{b}}$ & 0.00 & 0.00 & $15.92^{\mathrm{d}}$ & $15.95^{\mathrm{d}}$ & 0.00 & 0.00 & 0.00 & 0.00 \\
\hline $\mathrm{O}$ & $12.00^{\mathrm{a}}$ & $12.00^{\mathrm{a}}$ & $8.00^{\mathrm{b}}$ & $8.00^{\mathrm{b}}$ & $4.00^{\mathrm{c}}$ & $4.00^{\mathrm{c}}$ & $12.00^{\mathrm{d}}$ & $12.00^{\mathrm{d}}$ & $3.00^{\mathrm{e}}$ & $3.00^{\mathrm{e}}$ & $3.00^{\mathrm{e}}$ & $3.00^{\mathrm{e}}$ \\
\hline
\end{tabular}

Samples analysed were A4, A5 and A7. The calculated An (\%), Ab (\%), and Or (\%) for albite, range from 0.4 to $6.4,93.5$ to 99.6 and $\approx 0.1$, respectively.

1 Vein fill epidote (Band B), 2 epidote from alteration zone, 3 vein fill sericite (Band B), 4 sericite from alteration zone, 5 vein fill albite, 6 albite from alteration zone, 7 vein fill chlorite, 8 chlorite from alteration zone, 9 vein fill calcite, 10 calcite from alteration zone, 11 vein fill ankerite, 12 ankerite from alteration zone

${ }^{a}$ Number of ions basis of 13 atoms of $(\mathrm{O}, \mathrm{OH})$

${ }^{\mathrm{b}}$ Number of ions basis of 10 atoms of $(\mathrm{O}, \mathrm{OH})$

${ }^{\mathrm{c}}$ Number of ions basis of 4 atoms of $\mathrm{O}$

${ }^{\mathrm{d}}$ Number of ions basis of 28 atoms of $(\mathrm{O}, \mathrm{OH})$

${ }^{\mathrm{e}}$ Number of ions basis of 3 atoms of $\mathrm{O}$ 
Table 2 Ore paragenesis and crustification banding of vein fill minerals

\begin{tabular}{|c|c|c|c|c|c|}
\hline \multirow{3}{*}{ Mineral stages } & \multicolumn{5}{|l|}{ Bands } \\
\hline & $\mathrm{A}^{\mathrm{a}}$ & $\mathrm{B}^{\mathrm{a}}$ & $\mathrm{C}^{\mathrm{a}}$ & $\mathrm{D}^{\mathrm{a}}$ & \\
\hline & & Stage I & Stage II & Stage III & Stage IV \\
\hline$T\left({ }^{\circ} \mathrm{C}\right)$ & $235-223$ & $213-177$ & $173-160$ & $160-125$ & $<100$ \\
\hline Milky quartz & 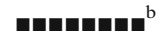 & 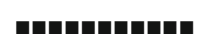 & & & \\
\hline Clear quartz & & & ตn日meng & " & m \\
\hline Calcite & & & ma & manen & \\
\hline Sericite & & שman & gmane & & \\
\hline Chlorite & & & m! & manan & \\
\hline Epidote & & घma & $m$ & & \\
\hline Albite & & ma & ma & & \\
\hline Ankerite & & man & mm & man & \\
\hline Sphalerite & & m & & & \\
\hline Pyrite & & $\mathbf{m}$ & & & \\
\hline Pyrrhotite & & - & & & \\
\hline Magnetite & & - & & & \\
\hline Arsenopyrite & & - & & & \\
\hline Argentite & & - & & - & \\
\hline Electrum & & - & & - & \\
\hline Stephanite & & - & & & \\
\hline Canfieldite & & - & & & \\
\hline Xanthoconite & & - & & & \\
\hline Proustite & & - & & & \\
\hline Tetrahedrite & & & m & & \\
\hline Chalcopyrite & & & 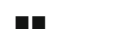 & & \\
\hline Famatinite & & & - & & \\
\hline Rammelsbergite & & & - & & \\
\hline Laggisite & & & - & & \\
\hline Cassiterite & & & - & & \\
\hline Galena & & & & man & \\
\hline Acanthite & & & & ! & \\
\hline Polybasite & & & & - & \\
\hline Argentopyrite & & & & - & \\
\hline Covellite & & & & & - \\
\hline Anglessite & & & & & ! \\
\hline Cerussite & & & & & ! \\
\hline Goethite & & & & & - \\
\hline Hematite & & & & & ma \\
\hline
\end{tabular}

${ }^{\mathrm{a}}$ The number of boxes represents the abundance.

${ }^{\mathrm{b}}$ Mineral stage I (bands A and B) is related to the NE-trending banded mineralized milky quartz veins, while stages II and III to the NW-trending banded mineralized clear quartz veins.

$\mathrm{Ag}_{5} \mathrm{SbS}_{4}$ Stephanite, $\mathrm{Ag}_{8} \mathrm{SnS} \mathrm{S}_{6}$ Canfieldite, $\mathrm{Ag}_{3} \mathrm{AsS}_{3}$ Xanthoconite, $\mathrm{Ag}_{3} \mathrm{AsS}_{3}$ Proustite, $\mathrm{Cu}_{3} \mathrm{SbS}_{4}$ Famatinite, (Ni,Co,Fe)As $\mathrm{s}_{2} \mathrm{Rammelsbergite,}$ $\mathrm{Co}_{0.8} \mathrm{Ni}_{0.2} \mathrm{As}$ Laggisite, $\mathrm{Ag}_{16} \mathrm{Sb}_{2} \mathrm{~S}_{11}$ Polybasite, $\mathrm{AgFe}_{2} \mathrm{~S}_{3}$ Argentopyrite.

medium-grained milky quartz matrix (Fig. 3b). Pyrite contains up to $2.24 \mathrm{wt} . \%$ As interpreted as native As nannoparticles (Table 3). Aggregates of intensely brecciated, anhedral and zoned sphalerite are intergrown with pyrite (Fig. 3b). Zoning in sphalerite is visible as green-brown cores and green-yellow rims reflecting zonation of the iron content, which range from 6.51 to 0.02 wt.\% (Fig. 3b). Sphalerite contains up to $11.3 \mathrm{~mol} \% \mathrm{FeS}$ in the cores and up to $0.4 \mathrm{~mol} \% \mathrm{FeS}$ in the rims (Table 3). Crystals with $\mathrm{Fe} /$ $\mathrm{Zn}+\mathrm{Fe}+\mathrm{Cb}+\mathrm{Co}$ values $<0.01$ are wurtzite and display a $\mathrm{Co} /$
$\mathrm{Fe}+\mathrm{Cu}+\mathrm{Co}$ ratio ranging up to 0.01 . Pyrite and sphalerite are intimately intergrown with fine-grained disseminations of subhedral arsenopyrite, anhedral hexagonal pyrrhotite and minor magnetite. Arsenopyrite with 44.44 to 44.85 wt. $\%$ As contains gold nannoparticles; so it appears, in some sites, rich in $\mathrm{Au}$ up to $1.12 \mathrm{wt} . \%$. Specks or laths of stephanite, proustite, xanthoconite, argentite and canfieldite (up to $1 \mathrm{~mm}$ ) are intergrown with pyrite and sphalerite. Electrum occurs as minute specks (up to $2 \mu \mathrm{m}$ ) and pseudo-cubic grains in intergrowths with sphalerite, pyrite and argentite. 
Table 3 Representative electron microprobe analyses compositions of native metals, sulfosalts, and sulfides from Apigania Bay

\begin{tabular}{|c|c|c|c|c|c|c|c|c|c|c|c|c|c|c|c|c|c|}
\hline Mineral & 1 & 2 core & $2 \mathrm{rim}$ & 3 & 4 & 5 & 6 & 7 & 8 & 9 & 10 & 11 & 12 & 13 & 14 & 15 & 16 \\
\hline \multicolumn{18}{|l|}{ Wt. $\%$} \\
\hline $\mathrm{Ag}$ & 0.05 & 0.00 & 0.00 & 0.00 & 83.75 & 82.19 & 19.93 & 17.93 & 63.70 & 65.51 & 73.33 & 68.08 & 0.00 & 0.03 & 3.49 & 60.03 & 34.02 \\
\hline $\mathrm{Cu}$ & 0.06 & 0.00 & 0.00 & 0.00 & 1.42 & 3.24 & 0.19 & 0.06 & 0.01 & 0.00 & 0.00 & 0.10 & 0.00 & 0.01 & 0.15 & 11.70 & 0.24 \\
\hline $\mathrm{Pb}$ & 0.15 & 0.00 & 0.01 & 0.00 & 0.15 & 0.25 & 0.00 & 0.00 & 0.00 & 0.00 & 0.00 & 0.00 & 0.00 & 0.04 & 83.22 & 0.01 & 0.03 \\
\hline $\mathrm{Zn}$ & 0.01 & 60.03 & 66.35 & 0.00 & 0.00 & 0.00 & 0.00 & 0.00 & 0.00 & 0.00 & 0.00 & 0.00 & 0.00 & 0.00 & 0.00 & 0.00 & 0.00 \\
\hline $\mathrm{Au}$ & 0.00 & 0.00 & 0.00 & $1.12 \mathrm{E}$ & 0.00 & 0.00 & 79.85 & 81.91 & 0.00 & 0.00 & 0.00 & 0.00 & 0.00 & 0.00 & 0.00 & 0.00 & 0.00 \\
\hline $\mathrm{Ni}$ & 0.01 & 0.00 & 0.00 & 0.01 & 0.00 & 0.00 & 0.00 & 0.00 & 0.00 & 0.00 & 0.00 & 0.00 & 27.83 & 8.77 & 0.00 & 0.00 & 0.00 \\
\hline $\mathrm{Fe}$ & 46.62 & 6.51 & 0.02 & 33.80 & 0.00 & 0.03 & 0.00 & 0.00 & 0.00 & 0.00 & 0.00 & 0.00 & 0.22 & 0.01 & 0.01 & 0.00 & 35.05 \\
\hline $\mathrm{Sn}$ & 0.00 & 0.00 & 0.00 & 0.00 & 0.00 & 0.00 & 0.00 & 0.00 & 0.00 & 0.00 & 10.13 & 0.00 & 0.00 & 0.00 & 0.00 & 0.00 & 0.00 \\
\hline $\mathrm{Co}$ & 0.09 & 0.03 & 0.00 & 0.01 & 0.00 & 0.00 & 0.00 & 0.00 & 0.00 & 0.00 & 0.00 & 0.00 & 2.53 & 35.18 & 0.00 & 0.00 & 0.00 \\
\hline $\mathrm{Te}$ & 0.00 & 0.00 & 0.00 & 0.00 & 1.62 & 0.79 & 0.02 & 0.04 & 0.00 & 0.00 & 0.00 & 0.00 & 0.00 & 0.00 & 0.00 & 0.20 & 0.00 \\
\hline As & $1.85 \mathrm{~F}$ & 0.01 & 0.00 & 44.85 & 0.01 & 0.01 & 0.00 & 0.01 & 15.02 & 14.99 & 0.00 & 1.50 & 68.28 & 55.53 & 0.00 & 1.52 & 0.19 \\
\hline $\mathrm{Sb}$ & 0.00 & 0.00 & 0.00 & 0.00 & 0.01 & 0.01 & 0.00 & 0.01 & 1.22 & 0.50 & 0.00 & 13.80 & 0.03 & 0.05 & 0.02 & 8.14 & 0.05 \\
\hline $\mathrm{S}$ & 50.83 & 33.41 & 33.61 & 20.10 & 12.61 & 12.52 & 0.00 & 0.01 & 19.90 & 18.99 & 16.52 & 15.89 & 0.46 & 0.09 & 13.10 & 18.30 & 30.18 \\
\hline Total & 99.67 & 99.99 & 99.99 & 99.89 & 99.57 & 99.04 & 99.99 & 99.97 & 99.85 & 99.99 & 99.98 & 99.37 & 99.38 & 99.71 & 99.99 & 99.95 & 99.77 \\
\hline \multicolumn{18}{|c|}{ No. of atoms based on } \\
\hline $\mathrm{Ag}$ & 0.00 & 0.00 & 0.00 & 0.00 & $1.96^{\mathrm{e}}$ & $1.87^{\mathrm{e}}$ & $0.33^{g}$ & $0.31^{\mathrm{g}}$ & $2.93^{\mathrm{h}}$ & $3.00^{\mathrm{h}}$ & 8.00 & $4.99^{\mathrm{j}}$ & 0.00 & 0.00 & $0.07^{\mathrm{n}}$ & $12.02^{\circ}$ & $0.98^{\mathrm{r}}$ \\
\hline $\mathrm{Cu}$ & $0.01^{\mathrm{a}}$ & 0.00 & 0.00 & 0.00 & $0.04^{\mathrm{e}}$ & $0.13^{\mathrm{e}}$ & 0.00 & 0.00 & $0.07^{\mathrm{h}}$ & 0.00 & 0.00 & $0.01^{\mathrm{j}}$ & 0.00 & 0.00 & 0.00 & $3.98^{\circ}$ & $0.02^{r}$ \\
\hline $\mathrm{Pb}$ & 0.00 & 0.00 & 0.00 & 0.00 & 0.00 & 0.00 & 0.00 & 0.00 & 0.00 & 0.00 & 0.00 & 0.00 & 0.00 & 0.00 & $0.92^{\mathrm{n}}$ & 0.00 & 0.00 \\
\hline $\mathrm{Zn}$ & 0.00 & $1.01^{\mathrm{c}}$ & $0.92^{\mathrm{c}}$ & 0.00 & 0.00 & 0.00 & 0.00 & 0.00 & 0.00 & 0.00 & 0.00 & 0.00 & 0.00 & 0.00 & 0.00 & 0.00 & 0.00 \\
\hline $\mathrm{Au}$ & 0.00 & 0.00 & 0.00 & $0.01^{\mathrm{d}}$ & 0.00 & 0.00 & $0.67^{\mathrm{g}}$ & $0.69^{\mathrm{g}}$ & 0.00 & 0.00 & 0.00 & 0.00 & 0.00 & 0.00 & 0.00 & 0.00 & 0.00 \\
\hline $\mathrm{Ni}$ & 0.00 & 0.00 & 0.00 & 0.00 & 0.00 & 0.00 & 0.00 & 0.00 & 0.00 & 0.00 & 0.00 & 0.00 & $0.91^{\mathrm{k}}$ & $0.20^{\mathrm{m}}$ & 0.00 & 0.00 & 0.00 \\
\hline $\mathrm{Fe}$ & $0.98^{\mathrm{a}}$ & 0.00 & $0.11^{\mathrm{c}}$ & $0.99^{d}$ & 0.00 & 0.00 & 0.00 & 0.00 & 0.00 & 0.00 & 0.00 & 0.00 & $0.01^{\mathrm{k}}$ & 0.00 & 0.00 & 0.00 & 2.00 \\
\hline $\mathrm{Sn}$ & 0.00 & 0.00 & 0.00 & 0.00 & 0.00 & 0.00 & 0.00 & 0.00 & 0.00 & 0.00 & 1.00 & 0.00 & 0.00 & 0.00 & 0.00 & 0.00 & 0.00 \\
\hline $\mathrm{Co}$ & $0.01^{\mathrm{a}}$ & 0.00 & 0.00 & 0.00 & 0.00 & 0.00 & 0.00 & 0.00 & 0.00 & 0.00 & 0.00 & 0.00 & $0.08^{\mathrm{k}}$ & $0.80^{\mathrm{m}}$ & 0.00 & 0.00 & 0.00 \\
\hline $\mathrm{Te}$ & 0.00 & 0.00 & 0.00 & 0.00 & $0.02^{\mathrm{f}}$ & $0.01^{\mathrm{f}}$ & 0.00 & 0.00 & 0.00 & 0.00 & 0.00 & 0.00 & 0.00 & 0.00 & 0.00 & $0.02^{\mathrm{q}}$ & 0.00 \\
\hline $\mathrm{Sb}$ & 0.00 & 0.00 & 0.00 & 0.00 & 0.00 & 0.00 & 0.00 & 0.00 & $0.05^{\mathrm{j}}$ & $0.02^{\mathrm{i}}$ & 0.00 & $0.85^{\mathrm{i}}$ & 0.00 & 0.00 & 0.00 & $1.54^{\mathrm{p}}$ & 0.00 \\
\hline As & $0.04^{\mathrm{b}}$ & 0.00 & 0.00 & 1.00 & 0.00 & 0.00 & 0.00 & 0.00 & $0.95^{\mathrm{j}}$ & $0.98^{\mathrm{i}}$ & 0.00 & $0.15^{\mathrm{i}}$ & $0.98^{1}$ & 1.00 & 0.00 & $0.46^{\mathrm{p}}$ & 0.00 \\
\hline $\mathrm{S}$ & $1.96^{\mathrm{b}}$ & 1.05 & 1.04 & 1.00 & $0.98^{\mathrm{f}}$ & $0.99^{\mathrm{f}}$ & 0.00 & 0.00 & 3.00 & 3.00 & 6.00 & 4.00 & $0.02^{1}$ & 0.00 & 1.00 & $10.98^{q}$ & 2.99 \\
\hline $\mathrm{As} / \mathrm{As}+\mathrm{S}$ & 0.03 & 0.00 & 0.00 & 0.00 & 0.00 & 0.00 & 0.00 & 0.00 & 0.00 & 0.00 & 0.00 & 0.00 & 0.00 & 0.00 & 0.00 & 0.00 & 0.00 \\
\hline A & 0.01 & 0.00 & 0.00 & 0.00 & 0.00 & 0.00 & 0.00 & 0.00 & 0.00 & 0.00 & 0.00 & 0.00 & 0.00 & 0.00 & 0.00 & 0.00 & 0.00 \\
\hline B & 0.00 & 0.00 & 0.03 & 0.00 & 0.00 & 0.00 & 0.00 & 0.00 & 0.00 & 0.00 & 0.00 & 0.00 & 0.00 & 0.00 & 0.00 & 0.00 & 0.00 \\
\hline $\mathrm{C}$ & 0.00 & 0.01 & 0.00 & 0.2 & 0.00 & 0.00 & 0.00 & 0.00 & 0.00 & 0.00 & 0.00 & 0.00 & 0.00 & 0.00 & 0.00 & 0.00 & 0.00 \\
\hline D & 0.00 & 0.01 & 0.00 & 0.2 & 0.00 & 0.00 & 0.00 & 0.00 & 0.00 & 0.00 & 0.00 & 0.00 & 0.00 & 0.00 & 0.01 & 0.00 & 0.00 \\
\hline
\end{tabular}

Samples analyzed were A1, A3, A5, A6, A7, A9, and A10.

1 Pyrite from Stage I (Band B), 2 sphalerite from Stage I (Band B), 3 arsenopyrite from Stage I (Band B), 4 argentite from Stage I (Band B), 5 acanthite from Stage III (Band D), 6 electrum from Stage I (Band B), 7 electrum from Stage III (Band D), 8 xanthoconite from Stage I (Band B), 9 proustite from Stage I (Band B), 10 canfieldite from Stage I (Band B), 11 stephanite from Stage I (Band B), 12 rammelsbergite (with rose to green-blue anisotropy) from Stage II (Band C), 13 laggisite from Stage II (Band C), 14 galena from Stage III (Band D), 15 polybasite from Stage III (Band D), 16 argentopyrite from Stage III (Band D); $A \mathrm{Cu}+\mathrm{Co} / \mathrm{Fe}+\mathrm{Cu}+\mathrm{Co}, B \mathrm{Fe} / \mathrm{Zn}+\mathrm{Fe}+\mathrm{Cb}+\mathrm{Co}, C \mathrm{Co} / \mathrm{Fe}+\mathrm{Cu}+\mathrm{Co}, D \mathrm{Cu} / \mathrm{Pb}+\mathrm{Fe}+$ $\mathrm{Cu}+\mathrm{Co}, E \mathrm{Au}$ inclusion, $F$ As inclusion

${ }^{\mathrm{a}} \mathrm{Fe}+\mathrm{Co}+\mathrm{Cu}=1$

${ }^{\mathrm{b}} \mathrm{As}+\mathrm{S}=2$

${ }^{\mathrm{c}} \mathrm{Zn}+\mathrm{Fe}=1$

${ }^{\mathrm{d}} \mathrm{Fe}+\mathrm{Au}=1$

${ }^{\mathrm{e}} \mathrm{Ag}+\mathrm{Cu}=2$

${ }^{\mathrm{f}} \mathrm{S}+\mathrm{Te}=1$

${ }^{\mathrm{g}} \mathrm{Au}+\mathrm{Ag}=1$

${ }^{\mathrm{h}} \mathrm{Ag}+\mathrm{Cu}=3$

${ }^{\mathrm{i}} \mathrm{As}+\mathrm{Sb}=1$

${ }^{\mathrm{j}} \mathrm{Ag}+\mathrm{Cu}=1$

${ }^{\mathrm{k}} \mathrm{Ni}+\mathrm{Co}+\mathrm{Fe}=1$

${ }^{1} \mathrm{As}+\mathrm{S}=1$

${ }^{\mathrm{m}} \mathrm{Co}+\mathrm{Ni}=1$

${ }^{\mathrm{n}} \mathrm{Pb}+\mathrm{Ag}=1$

${ }^{\mathrm{o}} \mathrm{Ag}+\mathrm{Cu}=16$

${ }^{\mathrm{p}} \mathrm{As}+\mathrm{Sb}=2$

${ }^{\mathrm{q}} \mathrm{S}+\mathrm{Te}=11$

${ }^{\mathrm{r}} \mathrm{Ag}+\mathrm{Cu}=1$ 
Stage II, which is associated with type C bands, is dominated by the granular and massive aggregates of tetrahedrite, famatinite, chalcopyrite, rammelsbergite $\left[(\mathrm{Ni}, \mathrm{Co}, \mathrm{Fe}) \mathrm{As}_{2}\right]$, laggisite $\left[\mathrm{Co}_{0.8} \mathrm{Ni}_{0.2} \mathrm{As}\right]$ and cassiterite (Tombros and St. Seymour 2003). These minerals form massive grains and are commonly interstitial to finegrained clear quartz. They replace stage I pyrite and sphalerite and were themselves replaced by galena (stage III). Intergrowths of tetrahedrite, famatinite and chalcopyrite occur as irregular masses of subhedral or anhedral crystals. Tetrahedrite contains up to $1.14 \mathrm{wt} . \% \mathrm{Ni}$ and has a $\mathrm{Sb} /(\mathrm{As}+\mathrm{Sb})$ ratio of 0.99 . Tetrahedrite and chalcopyrite contain large inclusions of rammelsbergite and laggisite. Occasionally chalcopyrite is intergrown with cassiterite and commonly replaced by covellite (Tombros and St. Seymour 2003).

The central parts of the veins (type D bands) are characterized by stage III galena and argentite-acanthite, polybasite $\left[\mathrm{Ag}_{16} \mathrm{Sb}_{2} \mathrm{~S}_{11}\right]$, electrum and argentopyrite. Coarse-grained crystals of galena occur in massive aggregates, strongly deformed and replaced by cerussite and anglesite (Fig. 3c). Polybasite, argentite in intergrowths with acanthite, electrum and argentopyrite occur in association with galena (Fig. 3c). Stage I argentite contains up to $1.2 \mathrm{wt} . \% \mathrm{Cu}$ and $1.6 \mathrm{wt} . \%$, Te, whereas stage III acanthite up to 3.4 wt. $\% \mathrm{Cu}$ and 0.8 wt.\% Te (Table 3). Stage I electrum bears $79.85 \mathrm{wt} . \% \mathrm{Au}$ (finess of 0.683 ) and up to 0.19 wt. $\% \mathrm{Cu}$, whereas stage III electrum contains 81.91 wt.\% Au (finess of 0.672) and traces of $\mathrm{Cu}$ (Table 3).

\section{Fluid inclusion studies}

Fluid inclusion data were obtained from milky and clear quartz (vein fill, epidote and chlorite zone), from fine- to medium-grained calcite, and stage I-sphalerite (Table 4). Fluid inclusions used in microthermometric studies ranged from 5 to $25 \mu \mathrm{m}$ in length and their nature was based on the criteria of Roedder (1984). They were considered as primary due to their formation adjacent to growth zones and to planar arrays outlining growth zones. Isolated inclusions within the crystals were also analyzed. Secondary inclusions in milky quartz occurred in planes of healed fractures that cut across grain boundaries. Many of the primary milky quartz fluid inclusions studied were decrepitated, as they appear with halos of small secondary inclusions (Fig. 4).

At room temperature, only one type of fluid inclusions was identified: Type $\mathrm{L}-\mathrm{V}$ inclusions consist of aqueous liquid+vapor, with the liquid phase being dominant in most inclusions (10 to 20 vol.\%). Temperatures of initial ice melting $\left(\mathrm{T}_{\mathrm{e}}\right)$ of these inclusions range from $-47.2^{\circ} \mathrm{C}$ to $34.0^{\circ} \mathrm{C}$, suggesting the presence of appreciable $\mathrm{CaCl}_{2}$ in addition to $\mathrm{NaCl}$ (Oakes et al. 1990). Temperatures of last melting of ice range from $-4.3^{\circ} \mathrm{C}$ to $-0.1^{\circ} \mathrm{C}$. Using the equation of Brown and Lamb (1989), the salinities range from of 0.2 to $6.8 \mathrm{wt} . \% \mathrm{NaCl}$ equivalent (Table 4). No gas hydrates were observed during freezing and no daughter crystalline solids were identified.

The $\mathrm{L}-\mathrm{V}$ fluid inclusions homogenize to the liquid phase, upon heating, from $235^{\circ} \mathrm{C}$ to $125^{\circ} \mathrm{C}$ (Figs. 4 and 5, Table 4). As suggested by Roedder (1984) a pressure correction of $+5^{\circ} \mathrm{C}$

Table 4 Fluid inclusion microthermometric data for primary liquid-vapor inclusions from Apigania Bay

\begin{tabular}{|c|c|c|c|c|c|c|c|}
\hline Sample ${ }^{a}$ & Mineral & V/L\% & $\begin{array}{l}T_{\mathrm{e}} \\
\text { Range }\end{array}$ & $\begin{array}{l}T_{\mathrm{m}} \\
\text { Range }\end{array}$ & $\begin{array}{l}T_{\mathrm{h}} \\
\text { Range }\end{array}$ & $\begin{array}{l}\text { wt.\% } \mathrm{NaCl} \\
\text { Range }\end{array}$ & $\begin{array}{l}\text { Density } \\
\text { Range }\end{array}$ \\
\hline A10 & 2 & 4 to 22 & -47 to -41 & -4.3 to -2.3 & 195 to 212 & 3.4 to 6.8 & 0.88 to 0.91 \\
\hline A6 & 2 & 7 to 12 & -43 to -40 & -3.6 to -2.3 & 203 to 210 & 3.0 to 5.0 & 0.89 to 0.91 \\
\hline A5 & 1 & 10 to 20 & -45 to -39 & -3.6 to -0.4 & 173 to 235 & 3.5 to 5.8 & 0.86 to 0.90 \\
\hline A6 & 1 & 12 to 22 & -45 to -40 & -3.7 to -2.2 & 217 to 220 & 3.8 to 5.9 & 0.88 to 0.90 \\
\hline A7 & 3 & 5 to 27 & -46 to -36 & -3.4 to -0.1 & 153 to 168 & 0.2 to 5.5 & 0.91 to 0.96 \\
\hline $\mathrm{A} 4$ & 3 & 2 to 19 & -36 to -34 & -3.6 to -0.1 & 151 to 162 & 1.3 to 5.2 & 0.87 to 0.97 \\
\hline A10 & 4 & 5 to 10 & -42 to -40 & -3.0 to -1.1 & 125 to 143 & 1.8 to 3.3 & 0.95 to 0.97 \\
\hline A10 & 5 & 7 to 10 & -41 to -38 & -3.0 to -2.3 & 193 to 197 & 3.7 to 4.9 & 0.90 to 0.93 \\
\hline A7 & 6 & 10 to 30 & -39 to -37 & -0.9 to -0.2 & 150 to 160 & 0.2 to 1.5 & 0.91 to 0.93 \\
\hline A7 & 7 & 11 to 20 & -39 to -38 & -0.8 to -0.7 & 138 to 143 & 1.2 to 1.3 & 0.96 to 0.97 \\
\hline $\mathrm{A} 1$ & 8 & 10 to 15 & -44 to -43 & -3.0 to -2.4 & 197 to 212 & 3.9 to 4.8 & 0.88 to 0.91 \\
\hline $\mathrm{A} 1$ & 9 & 15 to 20 & -46 to -38 & -3.4 to -0.7 & 151 to 166 & 1.2 to 5.1 & 0.91 to 0.95 \\
\hline $\mathrm{A} 1$ & 10 & 10 to 20 & -39 to -38 & -1.0 to -0.7 & 138 to 152 & 1.2 to 1.6 & 0.93 to 0.94 \\
\hline
\end{tabular}

Mineral: 1 Milky quartz from band A, 2 milky quartz from stage I and band B, 3 clear quartz from stage II and band C, 4 clear quartz from stage III and band D, 5 sphalerite from stage I and band B, 6 calcite from stage II and band C, 7 calcite from stage III and band D, 8 fine-grained milky quartz from epidote alteration zone 9 fine-grained clear quartz from chlorite alteration zone, 10 fine-grained calcite from chlorite alteration zone ${ }^{\mathrm{a}}$ The total of fluid inclusions analyzed were 50 


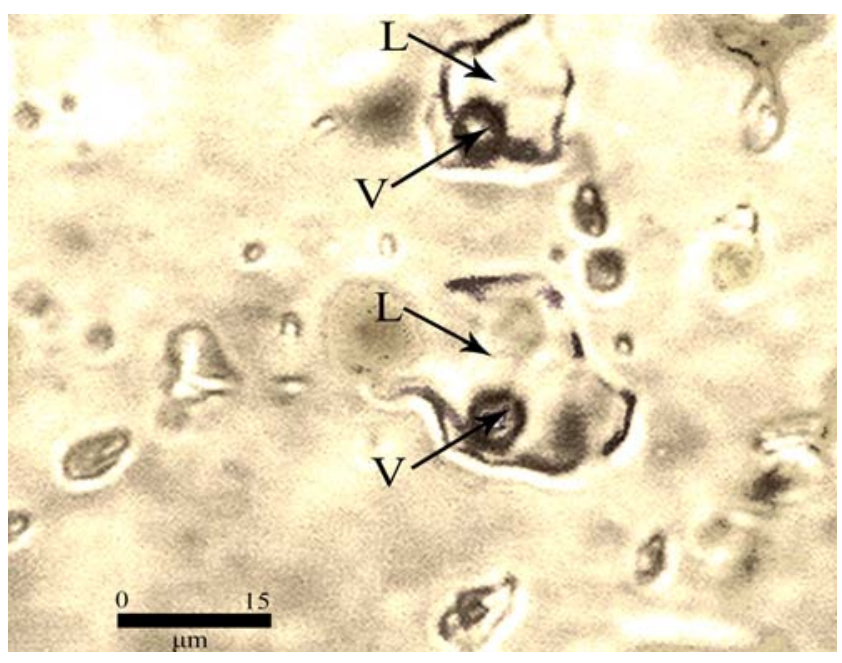

Fig. 4 Fluid inclusions in milky quartz veins, at the Apigania Bay, $\mathrm{Au}-\mathrm{Ag}$ mineralization. The inclusions are two-phase $\mathrm{L}-\mathrm{V}$ primary inclusions, which show evidence of decrepitation ( $L$ liquid, $V$ vapour)

was applied on homogenization temperatures up to $250^{\circ} \mathrm{C}$. The pressure correction was calculated by Flincor software using independent pressure determinations from the Tinos pluton $(P=7$ and $P=2 \mathrm{kbars}$ for the granodiorite and leucogranite, respectively; based on the Al-hornblende and garnet-biotitemuscovite-plagioclase geobarometers, Mastrakas 2007).

\section{Stable isotopes studies}

\section{Sulfur isotopes}

Sulfur isotope analyses were obtained on pyrite and sphalerite (stage I), chalcopyrite (stage II) and galena (stage III). The $\delta^{34} \mathrm{~S}$ values range from 0.0 to $-9.1 \%$ (Table 5). The calculated $\delta^{34} \mathrm{~S}_{\mathrm{H}_{2} \mathrm{~S}}$ values of the mineralizing fluids, using the fluid inclusions average homogenization temperatures reported in Table 5, range from -0.3 to $-7.3 \%$ (Table 5). The cores of sphalerite exhibited $\delta^{34} \mathrm{~S}$ values of $-0.4 \%$ and $-0.5 \%$, whereas the rims showed a value of $-4.7 \%$. These $\delta^{34} \mathrm{~S}$ values correspond to $\delta^{34} \mathrm{~S}_{\mathrm{H}_{2} \mathrm{~S}}$ values of $-0.9 \%$ o, $-1.0 \%$ o and $-5.5 \%$, respectively.

\section{Oxygen and hydrogen isotopes}

Oxygen and hydrogen isotope compositions are given in Table 6 and were obtained from fluids released from samples of vein milky and clear quartz. The $\delta^{18} \mathrm{O}$ and $\delta \mathrm{D}$ values of milky quartz range from $13.2 \%$ to $15.7 \%$ and $-85 \%$ to $-97 \%$ and of the epidote zone from $12.7 \%$ o to $14.7 \%$ and $-79 \%$ to $-94 \%$, respectively. For the calculations we have used the average temperature of fluid inclusions in milky and clear quartz, reported in Table 6 . The calculated $\delta^{18} \mathrm{O}$ and $\delta \mathrm{D}$ values of the mineralizing fluids range from $-0.6 \%$ to $1.7 \%$ o and $-80 \%$ to $-93 \%$, respectively (Fig. 7, Table 6).

Clear quartz in veins and alteration possesses $\delta^{18} \mathrm{O}$ and $\delta \mathrm{D}$ values of $15.9 \%$ to $18.0 \%$ and $-99 \%$ to $-112 \%$ o and of $15.8 \%$ to $16.5 \%$ and $-85 \%$ to $-101 \%$, respectively. The corresponding $\delta^{18} \mathrm{O}$ and values of the mineralizing fluid in equilibrium with clear quartz range from $-4.2 \%$ o to $-0.1 \%$ and $-90 \%$ to $-110 \%$, respectively. These values are approximately 3.0 (for $\delta^{18} \mathrm{O}$ ) and $30.0 \%$ (for $\delta \mathrm{D}$ ) heavier than of those of milky quartz, respectively. The isotopic $\delta^{18} \mathrm{O}$ compositions of the blueschists and greenschists of the Blueschists unit, range from $10.7 \%$ to $14.5 \%$ (Bröcker et al. 1993; Ganor et al. 1991, 1996).

\section{Carbon and oxygen isotopes of carbonates}

Carbon and oxygen isotope compositions were obtained from fine- to medium-calcite from clear quartz veins, and fine-
Fig. 5 Liquid-vapor homogenization temperature versus salinity plot in the $\mathrm{NaCl}-\mathrm{H}_{2} \mathrm{O}$ system from fluid inclusions of Apigania Bay and Panormos Bay mineralizations

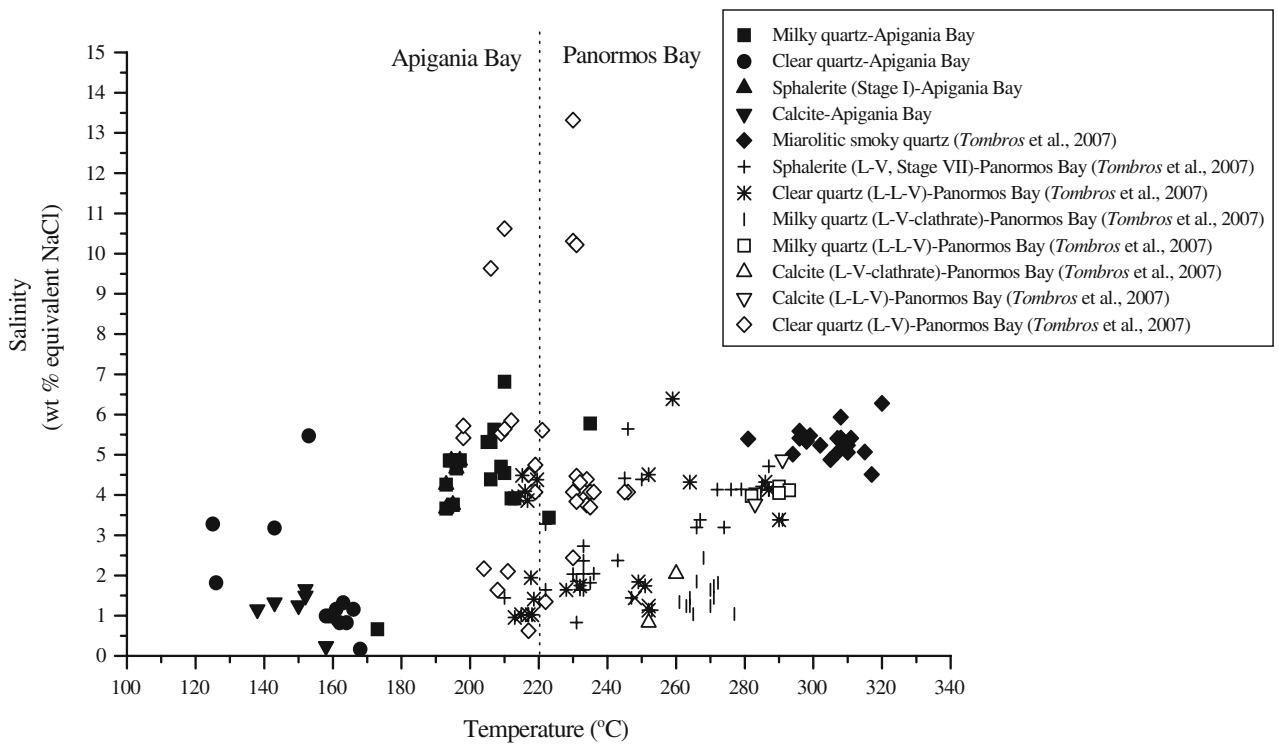


Table 5 Sulfur isotope compositions of pyrite, sphalerite, chalcopyrite and galena from Apigania Bay

\begin{tabular}{lcccc}
\hline Sample & Mineral & $T\left({ }^{\circ} \mathrm{C}\right)$ & $\delta \mathrm{S} 34$ & $\delta^{34} \mathrm{~S}_{-\mathrm{H}_{2} \mathrm{~S}}{ }^{\mathrm{a}}$ \\
\hline A7 & 1 & 200 & -0.2 & -0.9 \\
A1 & 1 & 195 & -0.3 & -1.0 \\
A6 & 1 & 205 & -0.5 & -0.8 \\
A6 & 2 & 200 & -0.5 & -0.8 \\
A5 & 2 & 210 & 0.0 & -0.3 \\
A6 & 2 & 205 & -0.1 & -0.7 \\
A10 & $2 \mathrm{a}$ & 195 & -0.4 & -0.9 \\
A10 & $2 \mathrm{~b}$ & 177 & -4.7 & -5.5 \\
A7 & $2 \mathrm{a}$ & 198 & -0.5 & -1.0 \\
A7 & 3 & 165 & -3.2 & -4.2 \\
A4 & 3 & 155 & -4.7 & -5.1 \\
A4 & 4 & 160 & -6.7 & -5.9 \\
A10 & 4 & 160 & -6.4 & -5.7 \\
A7 & 4 & 150 & -9.1 & -7.3 \\
A7 & 4 & 150 & -7.7 & -6.2 \\
\hline
\end{tabular}

Mineral: 1 Pyrite from stage I (band B), 2 sphalerite from stage I (band B), $2 a$ sphalerite cores, $2 b$ sphalerite rims, 3 chalcopyrite from stage II (band C), 4 galena from stage III (band D)

${ }^{a}$ Utilizing the $\mathrm{H}_{2} \mathrm{~S}-$-water equations of Ohmoto and Rye (1979), and Ohmoto and Lasaga (1982)

grained calcite from chlorite alteration zone. $\delta^{18} \mathrm{O}$ values are between $17.9 \%$ o to $19.2 \%$ (Table 7 ), whereas fine-grained calcite from chlorite zone yielded a value of $17.5 \%$ (Table 7). The calculated $\delta^{18} \mathrm{O}$ values of the fluids in equilibrium with calcite range from $9.0 \%$ to $10.3 \%$ (Table 7). An isotopic analysis was conducted on metamorphic calcite from the marbles of Blueschists unit and yielded $\delta^{18} \mathrm{O}$ values of $20.7 \%$. The corresponding calculated $\delta^{18} \mathrm{O}$ values for the fluid are of 16.9, assuming a metamorphic temperature of $400^{\circ} \mathrm{C}$ (Tombros et al. 2007). Reported $\delta^{18} \mathrm{O}$ values from dolomites and calcites in the marbles of the Blueschist unit range from $\sim 20.0 \%$ to $31.5 \%$, and $\sim 20$ to $29.1 \%$, respectively (Bröcker et al. 1993; Ganor et al. 1991, 1996).

The $\delta^{13} \mathrm{C}$ values for the same samples range from $0.85 \%$ to $1.2 \%$, corresponding to calculated values of $\delta^{13} \mathrm{Cco}_{2}$ from 0.7 to $1.1 \%$. A measured value of $\delta^{13} \mathrm{C}$ for a sample from the chlorite zone was $0.7 \%$, with a corresponding $\delta^{13} \mathrm{C}_{\mathrm{CO}_{2}}$ value of $0.6 \%$. Lastly, the sample of metamorphic calcite yielded $\delta^{13} \mathrm{C}$ values of $1.6 \%$, corresponding to $\delta^{13} \mathrm{C}_{\mathrm{CO}_{2}}$ value of 1.4 (Fig. 8, Table 7).

\section{Discussion}

\section{Fluid evolution}

The relationship between homogenization temperatures and salinities of fluids at Apigania Bay is displayed in Fig. 5 (with addition of selective fluid inclusions analyses from Panormos Bay for comparisons, Tombros et al. 2007). As it has already discussed for Panormos Bay, these trends indicate a history of $\mathrm{CO}_{2}$ effervescence (Tombros et al. 2007). $\mathrm{H}_{2} \mathrm{O}$-rich inclusions in milky quartz and clear quartz-calcite

Table 6 Oxygen and hydrogen isotope compositions of milky and clear quartz vein from Apigania Bay

\begin{tabular}{|c|c|c|c|c|c|c|}
\hline Sample & Mineral & $T\left({ }^{\circ} \mathrm{C}\right)$ & $\Delta^{18} \mathrm{O}$-quartz & $\delta^{18} \mathrm{O}$-water ${ }^{\mathrm{a}}$ & $\delta \mathrm{D}$-quartz & $\delta$ D-water ${ }^{\mathrm{b}}$ \\
\hline A10 & 1 & 235 & 13.9 & 1.7 & -89 & -85 \\
\hline A6 & 1 & 225 & 13.2 & 1.3 & -85 & -80 \\
\hline A10 & 1 & 223 & 14.6 & 1.5 & -93 & -90 \\
\hline A5 & 2 & 207 & 14.3 & 0.2 & -89 & -86 \\
\hline A10 & 2 & 212 & 14.9 & 1.2 & -95 & -92 \\
\hline A7 & 2 & 195 & 15.0 & -0.1 & -97 & -93 \\
\hline A6 & 2 & 200 & 15.7 & -0.6 & -94 & -90 \\
\hline A10 & 3 & 165 & 15.9 & -1.8 & -99 & -98 \\
\hline $\mathrm{A} 10$ & 3 & 150 & 16.8 & -2.4 & -108 & -102 \\
\hline A4 & 3 & 155 & 16.2 & -2.0 & -112 & -104 \\
\hline A7 & 4 & 143 & 17.0 & -2.8 & -111 & -107 \\
\hline A7 & 4 & 125 & 17.2 & -4.2 & -110 & -110 \\
\hline A7 & 4 & 130 & 18.0 & -4.7 & -120 & -114 \\
\hline $\mathrm{A} 1$ & 5 & 210 & 13.0 & 1.1 & -84 & -80 \\
\hline A6 & 5 & 205 & 12.7 & 0.8 & -79 & -84 \\
\hline A1 & 5 & 197 & 14.7 & 0.1 & -94 & -91 \\
\hline A10 & 6 & 166 & 15.8 & -0.1 & -92 & -90 \\
\hline A7 & 6 & 165 & 15.2 & -0.2 & -85 & -92 \\
\hline A 10 & 6 & 151 & 16.5 & -1.9 & -101 & -98 \\
\hline
\end{tabular}

Mineral: 1 Milky quartz from stage I (band A), 2 milky quartz from stage II (band B), 3 clear quartz from stage III (band C), 4 clear quartz from stage IV (band D), 5 milky quartz from epidote alteration zone, 6 clear quartz from chlorite alteration zone

${ }^{a}$ Utilizing the quartz-water equation of Clayton et al. (1972)

${ }^{\mathrm{b}}$ Utilizing the quartz-water, and muscovite-water equations of O’Neil and Taylor (1972), and Suzuoki and Epstein (1976) 
Table 7 Oxygen and carbon isotope data obtained from calcite at Apigania Bay

\begin{tabular}{lcccccc}
\hline Sample & Mineral & $\mathrm{T}\left({ }^{\circ} \mathrm{C}\right)$ & $\delta^{18} \mathrm{O}$ & $\delta^{18} \mathrm{O}_{\text {-water }}{ }^{\mathrm{a}}$ & $\delta \mathrm{C}^{13}$ & $\delta^{13} \mathrm{C}_{\text {fluid }}{ }^{\mathrm{b}}$ \\
\hline $\mathrm{A} 7$ & 1 & 165 & 17.9 & 9.2 & 0.85 & 0.7 \\
$\mathrm{~A} 7$ & 1 & 150 & 18.0 & 9.3 & 0.9 & 0.8 \\
$\mathrm{~A} 7$ & 2 & 145 & 18.9 & 10.1 & 1.0 & 0.9 \\
$\mathrm{~A} 7$ & 2 & 125 & 19.2 & 10.3 & 1.2 & 1.1 \\
A7 & 3 & 165 & 17.5 & 9.0 & 0.7 & 0.6 \\
A7 & 4 & $400^{\mathrm{C}}$ & 20.7 & 16.9 & 1.6 & 1.4 \\
\hline
\end{tabular}

Mineral: 1 Calcite from stage II and band C, 2 calcite from stage III and band D, 3 fine-grained calcite from chlorite alteration zone, 4 metamorphic calcite from Blueschist unit marbles

${ }^{a}$ Utilizing the calcite-water equation of O'Neil et al. (1969)

${ }^{\mathrm{b}}$ Utilizing the $\mathrm{CO}_{2}$-water equation of Ohmoto and Rye (1979)

${ }^{\mathrm{c}}$ Tombros (2001)

veins (Stage I and Stages II and III, respectively) display a parabolic trend of increasing salinities (from 3.4 to $6.8 \mathrm{wt}$. $\%$ equivalent $\mathrm{NaCl}$ and 0.2 to 5.5 wt.\% equivalent $\mathrm{NaCl}$ ) with decreasing temperatures (from $125^{\circ} \mathrm{C}$ to $235^{\circ} \mathrm{C}$; Fig. 5). This negative correlation can be attributed to either boiling of the hydrothermal fluid (Hedenquist and Henley $1985 \mathrm{a}, \mathrm{b}$ ) or tectonic uplift of the system, causing degassing due to depressurization (Vityk et al. 1994; Vityk and Bodnar 1995). Positive correlation of temperature and salinity in the same diagrams indicate that the hydrothermal fluids ores evolved due to mixing with local meteoric waters (Fig. 5).

For the early mineralizing stages a temperature interval of $235^{\circ} \mathrm{C}$ to $\approx 177^{\circ} \mathrm{C}$ is obtained, which ends with precipitation of stage I-minerals (Table 2), from dilute fluids (3.4 to $6.8 \mathrm{wt. \%}$ $\mathrm{NaCl}$ equivalent). Application of the pyrite-sphaleriteargentite-electrum geothermometer (Shikazono 1985), brackets stage I-ore assemblages between $177^{\circ} \mathrm{C}$ and $195^{\circ} \mathrm{C}$, whereas fluid inclusion temperatures in sphalerite indicate a range of $193^{\circ} \mathrm{C}$ to $197^{\circ} \mathrm{C}$ (Table 4). Clear quartz veins, which represent the later sulfide mineralization (stages II to III) were deposited between $176 \pm 0.5^{\circ} \mathrm{C}$ to $125^{\circ} \mathrm{C}$, as indicated by the coexistence of argentite-acanthite and fluid inclusion data, from low salinity fluids $(0.2$ to $5.5 \mathrm{wt} \%$ $\mathrm{NaCl}$ equivalent; Fig. 5).

The maximum pressure of fluid entrapment can be calculated from the thickness of the overlying Upper unit rock column, which at Apigania Bay area is estimated to be $\approx 1.5 \mathrm{~km}$ (Melidonis 1980). These depths correspond to a lithostatic pressure of 400 bars or a hydrostatic pressure of 150 bars. Geological features indicate that pressure conditions were hydrostatic (i.e., the high-porosity and abundance of vugs in marbles, the brittle character of mineralized fractures in schists, and the main occurrence of milky quartz veins as stockworks and of clear quartz veins with "openspace" filling and comb textures). A combined plot of temperatures versus pressure, for Apigania and Panormos Bay, suggests that the Apigania mineralization formed under hydrostatic pressures of 50 to 380 bars, with average of $\approx 100$ bars (Fig. 6). The continuation of pressure and temperature values indicates that the Apigania Bay mineralization could have formed at shallower levels (Fig. 6). Statistical analyses for the documented pressures for the fluid inclusion from milky and clear quartz, sphalerite and calcite reveal that the correlation coefficients were $0.59,0.61,0.77$, and 0.56 , respectively.

The fluid inclusion data reveal that there is a positive linear trend of decreasing temperatures and increasing pressures (Fig. 6). These trends (Figs. 5 and 6) can be explained by boiling and $\mathrm{CO}_{2}$-effervescence for the Panormos Bay mineralization, but cannot be the case for Apigania Bay because of the absence of vapor rich inclusions. Alternatively it can be explained by the decrepitation of the inclusions

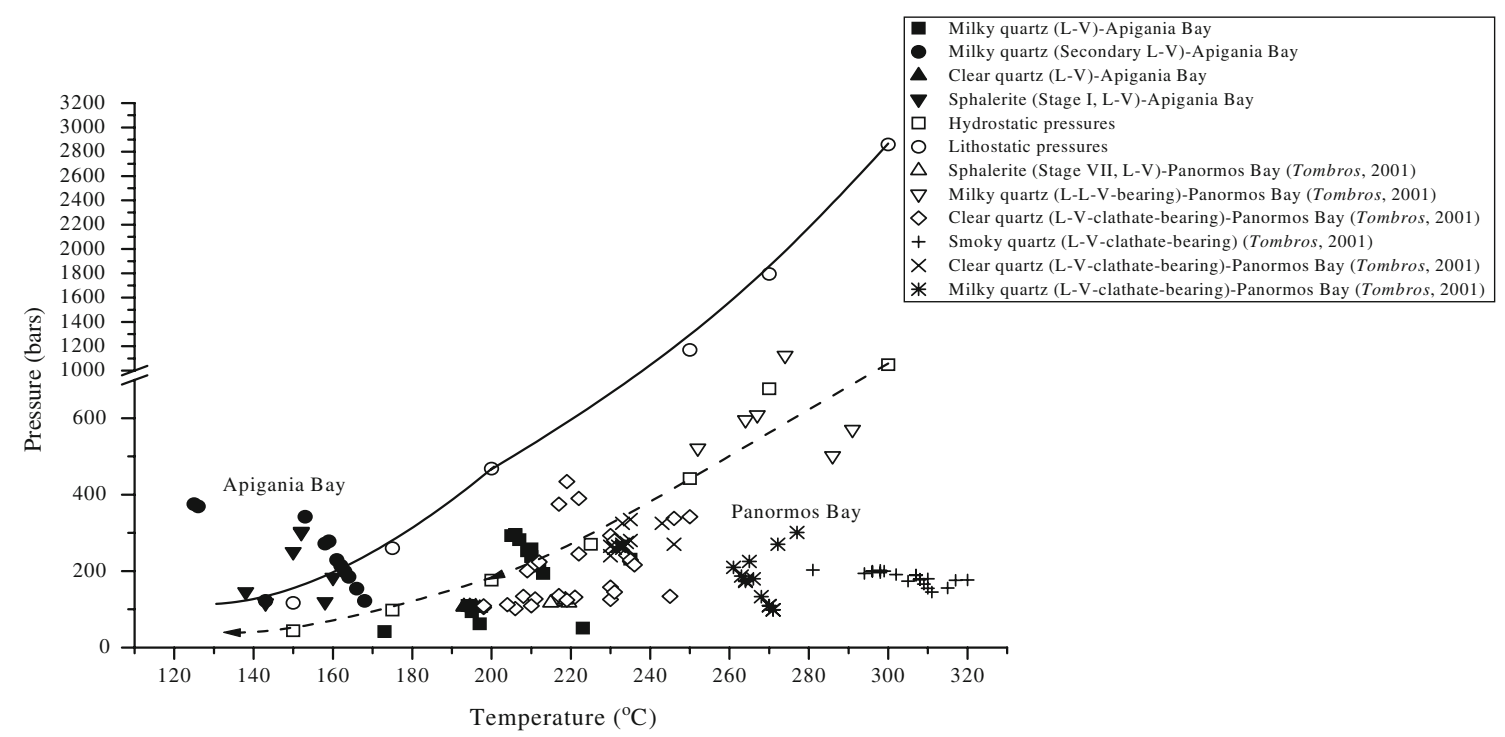

Fig. 6 Temperature versus pressure plot in the $\mathrm{NaCl}-\mathrm{H}_{2} \mathrm{O}$ system, from fluid inclusions from Apigania and Panormos Bay mineralizations 
due to rapid tectonic uplifting in successive steps. According to Roedder (1984), Vityk et al. (1994) and Vityk and Bodnar (1995) the external pressure of the fluid inclusions decreases rapidly during tectonic uplift with a slight drop of temperature (less than $\approx 50^{\circ} \mathrm{C}$ for Apigania Bay). This mechanism could produce overpressure conditions that will cause decrepitation of the inclusions, intense degassing and release of enough fluid to permit resealing of the inclusions leaving a fluid with higher density. It appears that in Apigania Bay the internal pressures recorded from fluid inclusions are greater than the confining pressures (Fig. 6).

Source of metallic and hydrothermal component

Regardless of the fact that the sulfur isotope data are few in number $(n=15)$, the calculated $\delta^{34} \mathrm{~S}_{\mathrm{H}_{2} \mathrm{~S}}$ values of mineralizing fluids show a considerable range of isotopic values ranging from $-0.9 \%$ to $-6.2 \%$ (Table 5). Values of $\delta^{34} \mathrm{~S}_{\mathrm{H}_{2} \mathrm{~S}}$ of stage I (i.e., $0 \%$ to $-1.0 \%$ ) exhibit a transitional minor magmatic to metasedimentary origin with contribution of sulfur from the Blueschist unit. Values of $\delta^{34} \mathrm{~S}_{\mathrm{H}_{2} \mathrm{~S}}$ throughout stages II and III, become progressively lighter (i.e. $-4.2 \%$ to $-7.3 \%$, respectively). The reason for such a progressive reduction in $\delta^{34} \mathrm{~S}_{\mathrm{H}_{2} \mathrm{~S}}$ values is possibly due to the progressive exchange of the ore fluid with the metamorphic country rocks. This hypothesis is supported by a single sample of pyrite from the Blueschist unit schists just $1 \mathrm{~km}$ away from Apigania Bay, which has a calculated sulfur isotope value of $-18.2 \%$ (Tombros et al. 2007).

Oxygen, hydrogen, and carbon isotope data suggest a combined magmatic-meteoric origin for the ore fluid. The $\mathrm{O}$ and $\mathrm{H}$ isotope compositions for the early and late stages of the Apigania Bay fluid reflect the dominance of meteoric waters, which evolved due to mixing and isotopic exchange, at low water-to-rock ratios (Fig. 7). A trend of decreasing $\delta^{13} \mathrm{C}_{\mathrm{CO}_{2}}$ compositions, with decreasing temperatures and increasing $\delta^{18} \mathrm{O}$ values indicates interaction of the ore fluids with the wall-rocks (Fig. 8). Sulfur isotopes also indicate a magmatic-metasedimentary origin in the early stages of mineralization. With falling temperature and increased fluid circulation, as mixing and wall-rock to fluid interactions proceed, gradual addition of sulfur is apparent due to increasing degree of leaching from a same source. The source of precious and other metals can be assigned to the metamorphic country rocks (Table 8 ). Trace element contents in the Apigania Bay mineralization suggest contribution to the ore fluid from the Blueschist unit and Upper unit rocks, although some of them were partly derived from Tinos leucogranite, which also acted as heat engine. The host rocks are characterized by high values of $\mathrm{Cu}$ (up to $676 \mathrm{ppm}$ ), $\mathrm{Zn}$ (up to $378 \mathrm{ppm}$ ), $\mathrm{Ag}$ (up to $372 \mathrm{ppm}$ ), Au (up to $592 \mathrm{ppm}$ ), V (up to $46 \mathrm{ppm}$ ), $\mathrm{Cd}$ (up to $4 \mathrm{ppm}$ ), $\mathrm{Sb}$ (up to $37 \mathrm{ppm}$ ) As (up to $67 \mathrm{ppm}$ ), $\mathrm{Cr}$ (up to $93 \mathrm{ppm}$ ), Co (up to $8 \mathrm{ppm}$ ) and $\mathrm{Ni}$ (up to $57 \mathrm{ppm}$ ). On the contrary leucogranite and miarolitic smoky quartz may have contributed $\mathrm{Pb}$ (up to $172 \mathrm{ppm}$ ), $\mathrm{Br}$ (up to $0.8 \mathrm{ppm}$ rich in volatiles), Sn (up to 1,000 ppm) and Ree's (Table 8).

Physicochemical conditions of metallic mineral formation

Chemical conditions of mineralization were estimated from phase stability relationships at temperatures of $200^{\circ} \mathrm{C}, 175^{\circ} \mathrm{C}$ and $150^{\circ} \mathrm{C}$ and the pressure of vapor-saturated liquid using SUPCRT92 (Johnson et al. 1992). All phases were considered to be ideal and individual ion activity coef-
Fig. 7 Hydrogen versus oxygen isotope diagram and histogram, displaying stable isotope systematics of hydrothermal fluids from Apigania Bay mineralization. The "Meteoric water line" and the "Subductionrelated vapor, arc and crystal felsic magma" (Hedenquist and Lowenstern 1994) are also displayed

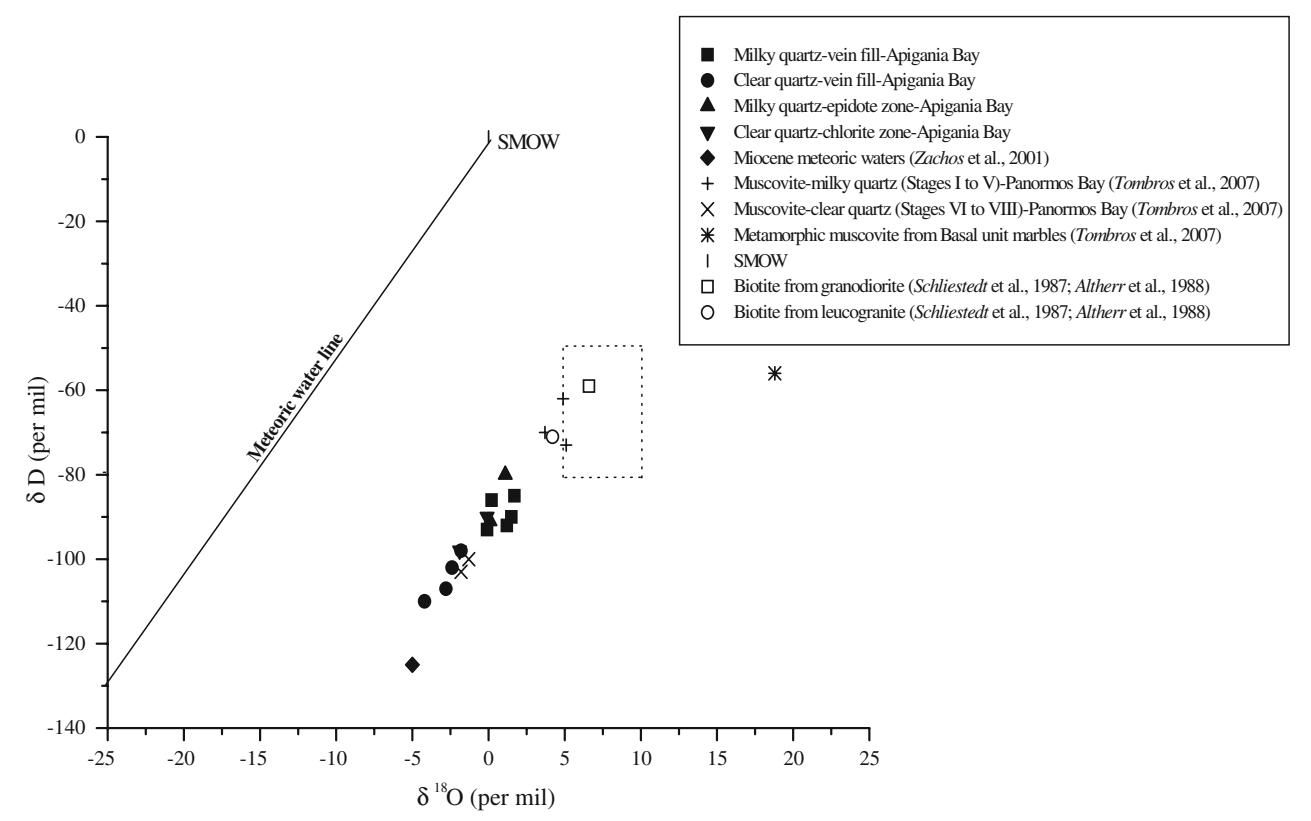




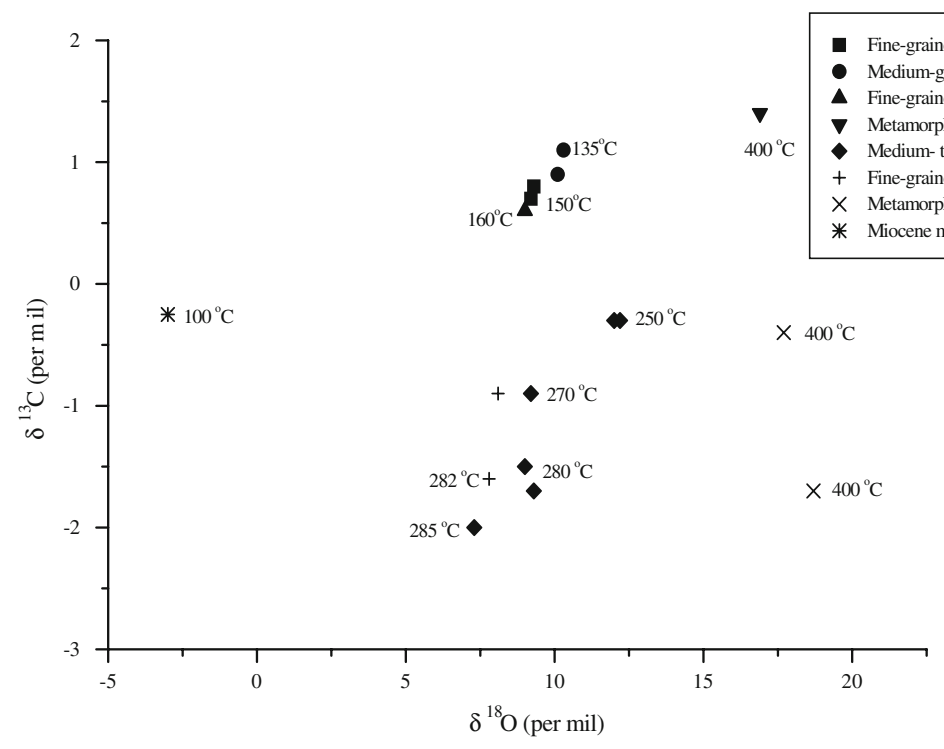

Fig. 8 Carbon versus oxygen isotope diagram from vein and alteration calcites, displaying stable isotope systematics of hydrothermal fluids from Apigania Bay mineralization. Temperatures represent the equilibrium temperatures obtained from fluid inclusions between calcite and clear quartz

ficients of dissolved species were derived from Helgeson and Kirkham (1974a, b), Harvie et al. (1984), Henley et al. (1984), Ahmad et al. (1987) and Zhang and Spry (1994).

From the reaction (1) $\log a_{\mathrm{SiO}_{2(\mathrm{aq})}}$ values of $-1.9,-2.5$ and -2.8 were derived at $200^{\circ} \mathrm{C}, 175^{\circ} \mathrm{C}$, and $150^{\circ} \mathrm{C}$, respectively:

$\mathrm{SiO}_{2(\mathrm{~s})}=\mathrm{SiO}_{2(\mathrm{aq})}$

Values of $\mathrm{pH}$ were obtained, at the same temperatures, from albite-sericite ( \pm quartz) equilibria (Eq. 2):

$$
\begin{aligned}
& \mathrm{KAlSi}_{3} \mathrm{O}_{8(\mathrm{~s})}+\mathrm{Na}_{(\mathrm{aq})}^{+}=\mathrm{NaAlSi}_{3} \mathrm{O}_{8(\mathrm{~s})}+\mathrm{K}_{(\mathrm{aq})}^{+} \\
& \mathrm{KAl}_{3} \mathrm{Si}_{3} \mathrm{O}_{10}(\mathrm{OH})_{2(\mathrm{~s})}+6 \mathrm{SiO}_{2(\mathrm{aq})}+3 \mathrm{Na}^{+} \\
& =3 \mathrm{NaAlSi}_{3} \mathrm{O}_{8(\mathrm{~s})}+2 \mathrm{H}^{+}+\mathrm{K}^{+}
\end{aligned}
$$

Based on the albite-orthoclase equilibrium (reaction 3 ) the calculated $\log (\mathrm{Na} / \mathrm{K})$ values were $0.64,0.78$ and 0.95 . These values correspond to activity coefficients of $\mathrm{Na}^{+}\left(\log \gamma_{\mathrm{Na}}^{+}\right)$ of $0.85,0.79$ and 0.72 [based on the Debye-Hückel expression of Helgeson et al. (1981), reaction 3], and concentrations of $\mathrm{Na}^{+}\left(m \gamma_{\mathrm{Na}}^{+}\right)$of $0.67,0.74$ and $0.81 \mathrm{mg} / \mathrm{l}$, respectively (based on the molal calculations obtained from salinities determinations of fluid inclusions studies; assuming that all salts are $\mathrm{NaCl}$ ). Using the latter concentrations the $\log a_{\mathrm{Na}}^{+}$values of $-0.38,-0.34$, and -0.45 were obtained at $200^{\circ} \mathrm{C}, 175^{\circ} \mathrm{C}$, and $150^{\circ} \mathrm{C}$, respectively, and $\mathrm{pH}$ values of $6.9,7.2$ and 7.6, respectively.

Using data from Barton and Toulmin (1964) and Barton (1980) for the assemblages pyrite-sphalerite-pyrrhotite and pyrite-sphalerite-electrum-argentite, respectively; values of $\log f_{\mathrm{S}_{2}}$ obtained for stages I and III are: for sphalerite cores and rims values of $\log f_{\mathrm{S}_{2}}=-16.8$, and -18.1 , and for the pyrite-sphalerite-electrum-argentite assemblage of $\log f_{\mathrm{S}_{2}}=-16.6$, and $\log f_{\mathrm{S}_{2}}=-17.7$, respectively. The assemblage of famatinite-tetrahedrite \pm chalcopyrite for $T=$ $175^{\circ} \mathrm{C}$, yields a maximum $\log f_{\mathrm{S}_{2}}$ value of -17.2 for stage II (Craig and Barton 1973). At $200^{\circ} \mathrm{C}$ the assemblage pyritepyrrhotite-magnetite "buffers" the $\log f_{\mathrm{O}_{2}}$ values at -44 (Barton and Skinner 1971; Barton and Toulmin 1964). The appearance of galena in stage III, in the absence of anglesite, at $T=150^{\circ} \mathrm{C}$ and $\mathrm{pH}=7.6$, requires a maximum $\log f_{\mathrm{O}_{2}}=$ -41.5 (Craig and Barton 1973).

$\mathrm{H}_{2} \mathrm{~S}_{(\mathrm{aq})}+\mathrm{O}_{2(\mathrm{~g})}=\mathrm{S}_{2(\mathrm{~g})}+2 \mathrm{H}_{2} \mathrm{O}_{(\mathrm{l})}$

$\mathrm{H}_{2} \mathrm{~S}_{(\mathrm{g})}=\mathrm{H}_{2} \mathrm{~S}_{(\mathrm{aq})}$

$\mathrm{H}_{2} \mathrm{~S}_{(\mathrm{aq})}=\mathrm{H}_{(\mathrm{aq})}^{+}+\mathrm{HS}_{(\mathrm{aq})}^{-1}$

$\mathrm{FeS}_{2(\mathrm{~s})}+2 \mathrm{H}_{(\mathrm{aq})}^{+}+\mathrm{H}_{2} \mathrm{O}_{(\mathrm{l})}=\mathrm{Fe}_{(\mathrm{aq})}^{+2}+2 \mathrm{H}_{2} \mathrm{~S}_{(\mathrm{aq})}+0.5 \mathrm{O}_{2(\mathrm{~g})}$

$\mathrm{ZnS}_{(\mathrm{s})}+2 \mathrm{H}_{(\mathrm{aq})}^{+}=\mathrm{Zn}_{(\mathrm{aq})}^{+2}+\mathrm{H}_{2} \mathrm{~S}_{(\mathrm{aq})}$

$0.25 \mathrm{O}_{2(\mathrm{~g})}+\mathrm{H}_{(\mathrm{aq})}^{+}+\mathrm{Au}_{(\mathrm{s})}=\mathrm{Au}_{(\mathrm{aq})}^{+}+0.5 \mathrm{H}_{2} \mathrm{O}_{(\mathrm{l})}$

$0.25 \mathrm{O}_{2(\mathrm{~g})}+\mathrm{H}_{(\mathrm{aq})}^{+}+\mathrm{Ag}_{(\mathrm{s})}=\mathrm{Ag}_{(\mathrm{aq})}^{+}+0.5 \mathrm{H}_{2} \mathrm{O}_{(\mathrm{l})}$ 
Table 8 Representative major (wt.\%) and trace (ppm) element analyses of vein and host rocks from the Apigania Bay

\begin{tabular}{|c|c|c|c|c|c|c|c|c|}
\hline & 1 & 2 & 3 & 4 & 5 & 6 & 7 & 8 \\
\hline $\mathrm{SiO}_{2}$ & 76.03 & 96.34 & 75.98 & 0.50 & 45.70 & 85.65 & 85.37 & 55.79 \\
\hline $\mathrm{TiO}_{2}$ & 0.03 & 0.01 & 0.03 & 0.02 & 0.08 & 0.01 & 0.01 & 1.31 \\
\hline $\mathrm{Al}_{2} \mathrm{O}_{3}$ & 13.35 & 0.05 & 13.22 & 0.57 & 15.14 & 0.27 & 0.03 & 10.26 \\
\hline $\mathrm{Fe}_{2} \mathrm{O}_{3}$ & 0.40 & 1.21 & 1.28 & 7.71 & 6.35 & 0.80 & 0.35 & 16.13 \\
\hline $\mathrm{MnO}$ & 0.17 & 0.00 & 0.01 & 0.01 & 0.01 & 0.00 & 0.00 & 0.20 \\
\hline $\mathrm{MgO}$ & 0.04 & 0.01 & 0.06 & 5.48 & 5.46 & 0.08 & 0.55 & 7.61 \\
\hline $\mathrm{CaO}$ & 0.46 & 0.02 & 1.08 & 53.58 & 20.49 & 11.52 & 12.72 & 4.17 \\
\hline $\mathrm{Na}_{2} \mathrm{O}$ & 3.24 & 1.31 & 3.22 & 0.01 & 2.72 & 0.01 & 0.02 & 2.78 \\
\hline $\mathrm{K}_{2} \mathrm{O}$ & 5.99 & 1.02 & 5.09 & 2.01 & 4.02 & 1.20 & 1.10 & 1.71 \\
\hline $\mathrm{P}_{2} \mathrm{O}_{5}$ & 0.02 & 0.00 & 0.02 & 0.01 & 0.02 & 0.08 & 0.02 & 0.01 \\
\hline LOI & 0.20 & 0.00 & 0.00 & 30.13 & 0.00 & 0.31 & 0.00 & 0.00 \\
\hline Total & 99.93 & 99.97 & 99.99 & 99.98 & 99.99 & 99.93 & 99.99 & 99.97 \\
\hline $\mathrm{Sr}$ & 13 & 22 & 67 & 357 & 871 & 15 & 437 & 70 \\
\hline $\mathrm{Y}$ & 53 & 20 & 13 & 12 & 8 & 5 & 35 & 13 \\
\hline $\mathrm{Zr}$ & 56 & 40 & 35 & 25 & 26 & 20 & 24 & 11 \\
\hline $\mathrm{Cu}$ & 4 & 8 & 2 & 676 & 14 & 20 & 6 & 40 \\
\hline $\mathrm{Pb}$ & 167 & 155 & 154 & 57 & 6 & 38 & 55 & 13 \\
\hline $\mathrm{Zn}$ & 28 & 23 & 7 & 282 & 378 & 211 & 11 & 45 \\
\hline $\mathrm{Ag}$ & 5 & 4 & 5 & 372 & 140 & 173 & 43 & 35 \\
\hline $\mathrm{Ni}$ & 2 & 8 & 2 & 37 & 36 & 9 & 3 & 57 \\
\hline $\mathrm{Cd}$ & 5 & 0.3 & 0.4 & 3.3 & 4 & 1.3 & 1 & 0.3 \\
\hline V & 2 & 2 & 2 & 40 & 46 & 2 & 8 & 145 \\
\hline $\mathrm{Au}$ & 2 & 5 & 40 & 352 & 592 & 202 & 1.5 & 15 \\
\hline As & 1 & 1.2 & 0.9 & 66 & 67 & 41 & 18 & 0.5 \\
\hline $\mathrm{Br}$ & 0.5 & 0.8 & 0.3 & 0.3 & 0.3 & 0.8 & 1.4 & 0.1 \\
\hline Co & 6 & 2 & 1 & 8 & 34 & 7 & 6 & 38 \\
\hline $\mathrm{Cr}$ & 17 & 11 & 1.5 & 28 & 26 & 6 & 5 & 93 \\
\hline Cs & 63 & 11 & 7 & 1 & 1 & 1 & 1 & 11 \\
\hline $\mathrm{Hf}$ & 5.1 & 2.1 & 1.7 & 0.5 & 0.6 & 0.8 & 0.8 & 1 \\
\hline $\mathrm{Rb}$ & 820 & 265 & 225 & 15 & 14 & 13 & 11 & 8 \\
\hline $\mathrm{Sb}$ & 1.5 & 0.2 & 0.2 & 18 & 37 & 7.2 & 0.3 & 0.6 \\
\hline Th & 15 & 25 & 11 & 0.3 & 0.6 & 0.2 & 0.4 & 0.9 \\
\hline $\mathrm{U}$ & 19.5 & 15 & 3.7 & 0.8 & 0.5 & 0.2 & 0.3 & 0.1 \\
\hline $\mathrm{Nb}$ & 66 & 3 & 3 & 1 & 1 & 1 & 1 & 1 \\
\hline $\mathrm{Sn}$ & 20 & 1000 & 980 & 2 & 1 & 875 & 192 & 2 \\
\hline $\mathrm{La}$ & 4.7 & 3.5 & 3.9 & 3 & 1.6 & 4.2 & 35 & 15 \\
\hline $\mathrm{Ce}$ & 13 & 10 & 9 & 6 & 4 & $<3$ & 49 & 39 \\
\hline $\mathrm{Nd}$ & 8 & 5 & 4 & 2 & 1 & 5 & 28 & 21 \\
\hline $\mathrm{Sm}$ & 2.9 & 0.7 & 0.6 & 0.8 & 0.4 & 0.5 & 5.2 & 6.4 \\
\hline $\mathrm{Eu}$ & 0.33 & 0.2 & 0.19 & 0.3 & 0.1 & 0.2 & 1.1 & 1 \\
\hline $\mathrm{Tb}$ & 1 & 0.5 & 0.5 & 0.2 & 0.1 & 0.2 & 1 & 0.6 \\
\hline $\mathrm{Yb}$ & 3.9 & 0.8 & 0.6 & 0.5 & 0.6 & 0.3 & 1.8 & 4.5 \\
\hline $\mathrm{Lu}$ & 0.6 & 0.2 & 0.1 & 0.1 & 0.1 & 0 & 0.3 & 0.8 \\
\hline
\end{tabular}

1 Tinos leucogranite (average of $n=7$ ), 2 smoky quartz (average of $n=2$ ), 3 aplites (average of $n=4$ ), 4 marbles of the Blueschists unit (average of $n=5$ ), 5 schists of the Blueschists unit (average of $n=5$ ), 6 milky quartz veins (average of $n=20$ ), 7 clear quartz veins (average of $n=20$ ), 8 schists of the upper unit (average of $n=15$ )

$$
\begin{aligned}
& 0.5 \mathrm{H}_{2} \mathrm{O}_{(\mathrm{l})}+0.7 \mathrm{Au}(\mathrm{HS})_{2(\mathrm{aq})}^{-}+0.3 \mathrm{Ag}(\mathrm{HS})_{2(\mathrm{aq})}^{-} \\
& =\mathrm{Au}_{0.7} \mathrm{Ag}_{0.3(\mathrm{~s})}+2 \mathrm{HS}_{(\mathrm{aq})}^{-}+\mathrm{H}_{(\mathrm{aq})}^{+}+0.25 \mathrm{O}_{2(\mathrm{~g})}
\end{aligned}
$$

$$
\mathrm{PbS}_{(\mathrm{s})}+2 \mathrm{H}_{(\mathrm{aq})}^{+}=\mathrm{Pb}_{(\mathrm{aq})}^{+2}+\mathrm{H}_{2} \mathrm{~S}_{(\mathrm{aq})}
$$

Using reactions 4, 5, 6, 7 and 8 , for $T=200^{\circ} \mathrm{C}$ and $\mathrm{pH}=6.9$, and $T=150^{\circ} \mathrm{C}$ and $\mathrm{pH}=7.6$ the values of $\operatorname{loga}_{\mathrm{H}_{2} \mathrm{~S}(\mathrm{aq})}=-2.6$ and $-3.4, \log a_{\mathrm{HS}}^{-}=-2.3$ and -3.3 , and $\log f_{\mathrm{H}_{2} \mathrm{~S}}=-2.2$ and -2.7 , were obtained, respectively. The calculated values of the ions $\mathrm{Fe}^{+2}$ and $\mathrm{Zn}^{+2}$, in solution, were $\log a_{\mathrm{Fe}^{+2}}=-5.7$ and $\log a \mathrm{Zn}^{+2}=-8.7$, corresponding to a ferrous and zinc content of 
Table 9 Calculated physicochemical parameters of stage I, II, and III fluids of Apigania Bay mineralization

\begin{tabular}{|c|c|c|c|}
\hline Physicochemical Parameters & Stage I & Stage II & Stage III \\
\hline Temperature $\left({ }^{\circ} \mathrm{C}\right)$ & $235-176.5$ & $176.5-160$ & $160-152$ \\
\hline $\mathrm{pH}$ & 6.9 & 7.2 & 7.6 \\
\hline $\log a_{\mathrm{SiO}_{2(\mathrm{aq})}}$ & -1.9 & -2.5 & -2.7 \\
\hline $\log f_{\mathrm{S}_{2}}$ & -16.8 to -18.1 & -17.2 & -17.7 \\
\hline $\log a_{\mathrm{H}_{2} \mathrm{~S}_{(\mathrm{aq})}}$ & -2.6 & - & -2.7 \\
\hline $\log f_{\mathrm{H}_{2} \mathrm{~S}_{(\mathrm{g})}}$ & -2.2 & - & -3.4 \\
\hline $\log _{\mathrm{HS}}^{-}(\mathrm{aq})$ & -2.3 & - & -3.3 \\
\hline $\log f_{\mathrm{O}_{2}}$ & -44 & - & -41.5 \\
\hline $\log a_{\mathrm{Fe}^{+2}}$ & -5.7 & - & - \\
\hline $\log a_{\mathrm{Zn}^{+2}}$ & -8.7 & - & - \\
\hline $\log a_{\mathrm{Au}^{+}}$ & -11.5 & - & -12.7 \\
\hline $\log a_{\mathrm{Ag}^{+}}$ & -14.4 & - & -15.7 \\
\hline $\log a_{\mathrm{Pb}^{+2}}$ & - & - & -7.3 \\
\hline
\end{tabular}

Mean temperatures for stages I, II, and III of $200^{\circ} \mathrm{C}, 175^{\circ} \mathrm{C}$ and $150^{\circ} \mathrm{C}$ and ionic strength $I=0.1$.

8.3 and $0.95 \mathrm{ppb}$, respectively (Table 9). Based on equilibriums 9, 10 and 11 for the formation of electrum at $T=190^{\circ} \mathrm{C}$ and $T=$ $150^{\circ} \mathrm{C}$ and $\mathrm{pH}=6.9$ and 7.6 respectively, the minimum calculated values of $\mathrm{Au}^{+}{ }_{\text {(aq) }}$ and $\mathrm{Ag}^{+}$(aq) are $\log a_{\mathrm{Au}^{+}}=-11.5$ and $\log a_{\mathrm{Ag}^{+}}=-14.4$ (stage I), and -12.7 and -15.7 (stage III). These values correspond to gold and silver concentrations of 1.3, 0.8, 1.0 and $0.4 \mathrm{ppb}$, respectively (Table 9), whereas values of $\log \left[a_{\mathrm{Au}^{+}} / a_{\mathrm{Ag}^{+}}\right]$range from 0.1 to 0.3 . From equilibrium 12 for galena, and stage III conditions, the minimum calculated value of $\mathrm{Pb}^{+2}$ (aq) is $\log a_{\mathrm{Pb}^{+2}}=-7.2$, corresponding to lead concentration of $1.8 \mathrm{ppb}$ (Table 9).

\section{Precipitation of ores}

There is an overall decrease in homogenization temperatures from type $\mathrm{A}$ to $\mathrm{D}$ crustification bands (type $\mathrm{A}$ bands are characterized by $T=235^{\circ} \mathrm{C}$ to $220^{\circ} \mathrm{C}$, for type $\mathrm{B}$ the $\mathrm{T}=$ $215^{\circ} \mathrm{C}$ to $170^{\circ} \mathrm{C}$, for type $\mathrm{C}$ the $T=168^{\circ} \mathrm{C}$ to $150^{\circ} \mathrm{C}$, and for type $\mathrm{D}$ the $T=145^{\circ} \mathrm{C}$ to $125^{\circ} \mathrm{C}$ ). This temperature drop was likely caused by mixing of the precious metal laden fluid with waters of meteoric origin, as it entered the intensely fractured hydrothermal system. This scenario is also reflected by stable isotope data (Fig. 7). The progressive decrease of average salinity with decreasing temperature (from $\approx 5$ wt. $\%$ NaCl-stage I to $\approx 0.2$ wt. $\%$ NaCl-stage III) suggests progressive dilution of the ore fluids with meteoric waters. Precipitation of base metal sulfides was the consequence of the temperature drop from $200^{\circ} \mathrm{C}$ to $177^{\circ} \mathrm{C}$, coupled with the decreasing $f_{\mathrm{S}_{2}}$ from -16.8 to -18.1 . Calcite deposition occurred at low temperatures $\left(\approx 160^{\circ} \mathrm{C}\right.$ to $\left.140^{\circ} \mathrm{C}\right)$ as a result of continuous cooling, dilution and mixing, and represents the final closure of the hydrothermal system (Fig. 5).
At Apigania Bay, there is evidence of decrepitation the inclusions. As it was pointed out by Avigad and Garfunkel (1991), Gautier and Brun (1994a, b), Avigad et al. (1994), Famin et al. (2004), Jolivet et al. (2003, 2004), Tinos hydrothermal system evolved into an interconnected network as the exhuming footwall moved rapidly to the surface. This uplift was controlled by large-scale enechelon normal-oblique faults accompany the Tinos extensional shear zone and the elongated dome due to a regional extensional stress field with NE-direction (Fig. 1b). Due to the uplift the external pressure of the fluid inclusions decreases rapidly, with a slight temperature drop, and resulted overpressure conditions which will produce degassing of the fluid. Escape of $\mathrm{H}_{2} \mathrm{~S}$ and $\mathrm{O}_{2}$ due to overpressure drove reactions 4 to the right and reactions 5 , $6,9,10$ and 11 to the left. As a consequence such conditions will produce intense hydraulic fracturing, increase in the $\mathrm{pH}$ into slightly alkaline of gold and silverbearing hydrothermal fluid and destabilization of the bisulphide ligand (Gammons and Williams-Jones 1995b). Deposition of native metal alloys, via reactions 9, 10 and 11 , coincided with a decrease in $f_{\mathrm{H}_{2} \mathrm{~S}}$ and $\mathrm{pH}$ from $10^{-2.6}$ and 6.9 , at $T=200^{\circ} \mathrm{C}$, to $10^{-3.4}$ and 7.6 , at $T=150^{\circ} \mathrm{C}$.

\section{Comparisons between the Apigania and Panormos Bay epithermal ore systems}

Although the Apigania and Panormos Bay mineralizations, are different by more than one feature; they share several geological, mineralogical, and geochemical attributes. These similarities suggest a common origin, but a different evolutionary phase of the same major ore event in the Tinos hydrothermal system. The Panormos Bay ores are hosted exclusively in the marbles of both the Basal and Blueschist units, whereas the Apigania Bay in the marbles and schists of the Blueschist unit. These ore systems exhibit the same styles of epithermal stockworks (i.e., the Panormos Bay mineralization is characterized by the abundance of numerous veins, more than thirty major against five; and of hydrothermal vein breccias, against of tectonic origin), in directions, steep faults, banding, and mineralogical sequence of earlier milky and later clear quartz veins.

Major differences in alteration patterns, include the formation of talc-brucite-calcite versus epidote-ankerite and chloriteepidote-ankerite versus chlorite-calcite paragenetic sequences (of the inner and outer zones, respectively). Ore paragenesis, generally, evolves from base metals in the early stages to precious metals in the late ones. Pyrite, tetrahedrite, chalcopyrite, $\mathrm{Ni-Co}$ arsenides, galena, and Sn-bearing minerals are common in both of the mineralizations. The occurrence of the Sn-minerals suggests the possible link to the Tinos pluton leucogranitic phase. The Panormos Bay assemblages contain 
exclusively tellurides (both of base and precious metals) and native precious metals, whereas the Apigania Bay precious metals are deposited, even in the early stages, as alloys (electrum) and $\mathrm{Ag}$-sulfosalts. In the Panormos Bay mineralization, pyrite contains $\mathrm{Au}$ (3.34 wt.) and $\mathrm{Te}(0.13 \mathrm{wt} \%$ ), whereas at Apigania Bay As (1.85 wt.\%) and $\mathrm{Ag}(0.15$ wt.\%), respectively. In comparison, arsenopyrite is As-rich, whereas sphalerite is Fe-poor. Chalcopyrite, tetrahedrite, and galena from Panormos Bay are rich in $\mathrm{Ag}$ (up to 1.2, 3.5 and $1.0 \mathrm{wt} . \%$ ) and Te (up to 6.5, 9.2, and 6.0 wt.\%). In both systems deposition of Ag-bearing minerals proceeded of the Aubearing, and $\mathrm{Sn}$ - and Ni, Cr-bearing phases are deposited.

Homogenization temperatures of Panormos Bay fluid inclusions were from $200^{\circ} \mathrm{C}$ to $300^{\circ} \mathrm{C}$, with the telluride ore to be precipitated from $230^{\circ} \mathrm{C}$ to $260^{\circ} \mathrm{C}$, and native precious metals below $210^{\circ} \mathrm{C}$, whereas at Apigania Bay the inclusions homogenize to liquid from $125^{\circ} \mathrm{C}$ to $235^{\circ} \mathrm{C}$, with the ores precipate from $150^{\circ} \mathrm{C}$ to $195^{\circ} \mathrm{C}$. Fluids responsible for Apigania Bay mineralization were non boiling, cooler $\left(\sim 235^{\circ} \mathrm{C}\right.$ to $\left.125^{\circ} \mathrm{C}\right)$, with salinities overlapping the ones of Panormos Bay ( 0.8 to 6.8, against 0.6 to 13.3 wt.\% $\mathrm{NaCl}$ equivalent). Ore-bearing fluids cooled, mixed, and progressively diluted from early to late stages in both systems. $\mathrm{CO}_{2}$-bearing fluid inclusions showing evidence for effervescence characterize the Panormos Bay (Tombros et al. 2007), whereas at the Apigania Bay decrepitated inclusions related to intensive uplift assisted deposition to shallower depths (at $\approx 100$ bars). The Panormos Bay mineralization has being deposited under the same hydrothermal conditions, from pressures below 500 bars, at the deeper parts of the hydrothermal system, although there is evidence of uplifting in the late stages.

The $\delta^{18} \mathrm{O}$ values from Apigania Bay overlap these from Panormos Bay (i.e., $-0.1 \%$ o to $1.7 \%$ against $-3.3 \%$ to $5.1 \%$, Tombros et al. 2007) whereas the $\delta \mathrm{D}$ values are heavier (i.e., $-62 \%$ to $-73 \%$ against $-100 \%$ o to $-103 \%$ ). There is a recognizable overlap of the obtained values from milky and clear quartz of the mineralizing fluid, and of the metamorphic rocks of the Blueschist unit. The values of water-to-rock ratios in the Apigania Bay rose up to $16 \%$, against the $6 \%$ from Panormos Bay (Tombros 2001). Calculations of waterto-rock ratios were performed by assuming an open system, based on the equations adopted from Taylor (1974). The Apigania Bay calculated $\delta^{34} \mathrm{~S}_{\mathrm{H}_{2} \mathrm{~S}}, \delta^{18} \mathrm{~S}_{\mathrm{H}_{2} \mathrm{O}}$, and $\delta^{13} \mathrm{C}_{\mathrm{CO}_{2}}$ values overlap the ones from Panormos Bay (i.e., $-0.3 \%$ o to $-5.9 \%$ against $0.8 \%$ o to $-10.5 \%$, $7.3 \%$ o to $12.2 \%$ against $9.0 \%$ to $10.3 \%$, and $0.6 \%$ to $1.1 \%$ against $-0.3 \%$ o to $-2.0 \%$, respectively, Tables 5, 7 and Fig. 8).

From the isotope data it appears that the Apigania Bay mineralizing fluid has been interacted with the metamorphic wall-rocks, and mixed with meteoric waters. This can be attributed to the alkaline nature of the fluid and the open character of the hydrothermal system, as it was revealed from the water-to-rock ratios calculations. Zoning in sphalerite also points out that the ore minerals were out of equilibrium and precipitated in an open environment. In the Panormos Bay system the contribution from magmatic fluids is apparent, and isotopic exchange with the marble wall-rocks is in a lesser degree. Metals and sulfur were mainly contributed from the metasedimentary Blueschist rocks, although a part of them could have been derived from the leucogranite. Likely sources of the host rocks for the metallic components in the Apigania Bay mineralization are the schists and marbles of the Blueschist unit, whereas in the Panormos Bay ore there is also contribution from the Basal and Upper unit rocks.

The Panormos Bay mineralizing fluid bears a more sulfidized, acidic, auriferous and telluric signature, whereas the Apigania Bay a more oxidized, $\mathrm{H}_{2} \mathrm{~S}$ and silver-bearing. In the Panormos Bay and Apigania Bay mineralization the major physicochemical parameters were: $\log f_{\mathrm{S}_{2}}=-10.9$ to -15.0 , and -16.8 to $-18.1, \log f_{\mathrm{O}_{2}}=-37.0$ to -41.0 , and -44.0 to $-41.5, \mathrm{pH}=4.6$ to 6.5 , and 6.9 to 7.6 , and $\log f_{\mathrm{H}_{2} \mathrm{~S}}=-1.7$ to -1.8 , and -2.2 to -3.4 , respectively.

The main difference between the two ore occurrences is the absence of tellurium deposition in the Apigania Bay. Possible explanations for the non deposition of tellurides can be attributed to the non occurrence of $\mathrm{CO}_{2}$ effervescence of the mineralizating fluid, in the absence of available tellurium content due to pre-deposition in the Panormos Bay, in the minor volume of the highly reactive marbles in the area and in absence of magnesium the marbles or in solution, which may have played a catalytic role and helped tellurium to condense. Experimental studies have showed that magnesium has the capacity to increase the rate of hydrogen dissociation, slow down its adsorption kinetics, and lead hydrogen-bearing gases to condense (Swartz et al. 1999). This hypothesis is supported by the presence of magnesium minerals in the most studied Ag-Au-Te ore deposits such as: dolomite-talc-brucite (Panormos Bay; Tombros et al. 2004, 2005, 2007), Mg-chlorite (Acupan; Cooke et al. 1996; Cooke and McPhail (2001), dolomite (Cripple Creek; Thompson et al. 1985; Kelley et al. 1998), dolomite and Mg-chlorite (Emperor, Tuvatu; Ahmad et al. 1987; Scherbarth and Spry 2006), roscoelite and dolomite (Porgera; Richards and Kerrich 1993; Ronacher et al. 2004) and Mg-chlorite and manganese ores (Sunnyside mine; Casadevall and Ohmoto 1977).

The Apigania Bay system could be regarded as a small occurrence contemporaneous to the Panormos Bay, which most likely formed at shallower crustal level (Fig. 6). Both of the mineralizations were most likely formed by the processes generated by the leucogranite phase of the Tinos pluton, with Apigania Bay representing the latest evolutionary phase of the hydrothermal system. The evolution of the mineralizing hydrothermal fluids began with the 
deposition of scheelite in the skarn rocks nearby Tinos granodiorite-leucogranite (Fig. 1b); continued with the tellurium-bearing precious metals ores at the Panormos Bay and ended with precious metals ores tellurium absent at Apigania Bay.

Acknowledgements The late Professor Nickolaus Melidonis geologically mapped Tinos and first reported the $\mathrm{Au}-\mathrm{Ag}$ mineralization at Apigania. Research funds for this work were obtained from government grants to KStS, and a "Pythagoras II" grant and post-doctoral fellowship to KStS and S. Tombros, respectively. We thank the European Social Fund (ESF), Operational Program for Educational and Vocational Training II (EPEAEK II), and particularly the Program PYTHAGORAS II, for funding the above work. We also want to thank Glenn Poirier for his assistance with electron microprobe analyses, and Nickolaus Mastrakas for his ideas.

Open Access This article is distributed under the terms of the Creative Commons Attribution NonCommercial License which permits any noncommercial use, distribution, and reproduction in any medium, provided the original author(s) and source are credited.

\section{References}

Ahmad M, Solomon M, Walshe JL (1987) Mineralogical and geochemical studies of the Emperor gold-telluride deposit, Fiji. Econ Geol 87:345-370

Altherr R, Siebel W (2002) I-type plutonism in a continental back-arc setting: miocene granitoids and monzonites from the central Aegean Sea, Greece. Cont Min Petr 143:397-415

Altherr R, Kreuzer H, Wendt I, Lenz H, Wagner GA, Keller J, Harre W, Hohndorf A (1982) A late Oligocene/Early Miocene high temperature belt in the attico-cycladic crystalline complex (SE Pelagonia, Greece). Geol Jahr 23:971-164

Avigad D, Garfunkel Z (1989) Low angle faults underneath and above a Blueschist Belt-Tinos Island, Cyclades, Greece. Terra Nova 2:182-187

Avigad D, Garfunkel Z (1991) Uplift and exhumation of high-pressure metamorphic terrains: the example of the Cycladic Blueschist Belt (Aegean Sea). Tectonophysics 188:357-372

Avigad D, Baer G, Heimann A (1994) Block rotation and continental extension in the central Aegean Sea: palaeomagnetic and structural evidence from Tinos and Mykonos (Cyclades, Greece). Ear Plan Sc Let 137:23-40

Barton MD (1980) The Ag-Au-S system. Econ Geol 75:303-316

Barton PB Jr, Toulmin P (1964) Experimental determination of the reaction chalcopyrite + sulfur $\rightarrow$ pyrite + bornite, from $350^{\circ}-500^{\circ} \mathrm{C}$. Econ Geol 59:747-752

Barton PB Jr, Skinner BJ (1971) Sulfide mineral stabilities. In: Barnes HL (ed) Geochemistry of the hydrothermal ore deposits. New York, Holt, Rinehart and Winston, pp 236-333

Blake MC Jr, Bonneau M, Geyssant J, Kienast JR, Lepvrier G, Maluski H, Papanikolaou D (1981) A geologic reconnaissance of the Cycladic Blueshists Belt, Greece. Geol Soc Amer Bull 92:247-254

Boronkay K (1995) Geotectonic evolution of the Cyclades. PhD Thesis, Univ. of Patras, p 193

Boronkay K, Doutsos T (1994) Transpression and transtension within different structural levels in the central Aegean region. J Struc Geol 16:1555-1573

Bröcker M (1990) Blueschist to greenschist transition in metabasites from Tinos Island, Cyclades, Greece. Compositional control or fluid infiltration? Lith 25:25-39
Bröcker M, Franz L (1994) The contact aureole on Tinos (Cyclades, Greece). Part I: field relationships, petrography and P-T conditions. Chem Erd 54:262-280

Bröcker M, Franz L (1998) Rb-Sr isotope studies on Tinos Island (Cyclades, Greece): additional time constraints for metamorphism, extent of infiltration-controlled overprinting and deformational activity. Geol Mag 135:369-382

Bröcker M, Enders M (1999) U-Pb zircon geochronology of unusual eclogite-facies rocks from Syros and Tinos (Cyclades, Greece). Geol Mag 136:111-118

Bröcker M, Franz L (2000) The contact aureole of Tinos, Cyclades, Greece: tourmaline-biotite geothermometry and $\mathrm{Rb}-\mathrm{Sr}$ geochronology. Miner Petrol 70:257-283

Bröcker M, Kreuzer H, Matthews A, Okrusch M (1993) ${ }^{40} \mathrm{Ar} /{ }^{39} \mathrm{Ar}$ and oxygen isotope studies of polymetamorphism from Tinos Island, Cycladic Blueschist Belt, Greece. J Metam Geol 11:223-240

Bröcker M, Bieling D, Hacker B, Gans P (2004) High-Si phengites record the time of greenschist-facies overprinting: implications for models suggesting mega-detachments in the Aegean Sea. J Metam Geol 22:427-442

Brown PE (1989) FLINCOR: a microcomputer program for the reduction and investigation of fluid inclusion data. Amer Miner 74:1390-1393

Brown PE, Lamb WE (1989) P-V-T properties of fluids in the system $\mathrm{NaCl} \pm \mathrm{H}_{2} \mathrm{O} \pm \mathrm{CO}_{2}$ : new graphical presentations and implications for fluid inclusions studies. Geochim Cosmochim Acta 53:1209-1221

Casadevall T, Ohmoto H (1977) Sunnyside mine, Eureka Mining District, San Juan Country, Colorado: geochemistry of gold and base metal ore deposition in a volcanic environment. Econ Geol 72:1285-1320

Clayton RN, Mayeda TK (1963) The use of bromine penta-fluoride in the extraction of oxygen from oxides and silicates for isotopic analysis. Geochim Cosmochim Acta 27:43-52

Clayton RN, Muffler LJP, White DE (1972) Oxygen isotope fractionation study of calcite and silicates of the River Ranch, California. Amer J Sc 266:968-979

Cooke DR, McPhail D (2001) Epithermal Au-Ag-Te mineralization, Acupan, Baguio district, Philippines: numeral simulations of mineral deposition. Econ Geol 96:109-132

Cooke DR, McPhail D, Bloom M (1996) Epithermal gold mineralization, Acupan, Baguio district, Philippines: geology, mineralization, alteration and the thermochemical environment of ore deposition. Econ Geol 94:243-272

Craig JR, Barton PB (1973) Thermochemical approximations for sulfosalts. Econ Geol 68:493-506

Famin V, Philippot P, Jolivet L, Agard P (2004) Evolution of hydrothermal regime along a crustal shear zone, Tinos Island, Greece. Tectonics 23:1-23

Friedman I, O'Neil JR (1977) Compilation of stable isotope fractionation factors of geochemical interest. US Geol Surv Pr Pap 440:1-12

Fritz P, Drimmie RJ, Norwick K (1974) Preparation of sulfur dioxide for mass spectrometer analysis by combustion of sulfide with copper oxide. Anal Chem 76:164-166

Gammons CH, Williams-Jones AE (1995b) Hydrothermal geochemistry of electrum: thermodynamic constraints. Econ Geol 90:420-432

Ganor J, Matthews A, Paldor N (1991) Diffusional isotopic exchange across an interlayered marble-schist sequence with an application to Tinos, Cyclades, Greece. J Geoph Res 96:18073-18080

Ganor J, Matthews A, Schliestedt M, Garfunkel Z (1996) Oxygen isotopic heterogeneities of metamorphic rocks: an original tectonostratigraphic signature or an imprint of exotic fluids? A case study of Sifnos and Tinos islands, (Greece). Eur J Min 8:719-732

Gautier P, Brun JP (1994a) Crustal-scale geometry and kinematics of late-orogenic extension in the central Aegean (Cyclades and Evoia island). Tectonophysics 238:399-424 
Gautier P, Brun JP (1994b) Ductile crust exhumation and extensional detachments in the central Aegean (Cyclades and Evia islands). Geodin Acta 7:57-85

Harvie CE, Møller N, Weare JH (1984) The prediction of mineral solubilities in natural waters: the $\mathrm{Na}-\mathrm{K}-\mathrm{Mg}-\mathrm{Ca}-\mathrm{H}-\mathrm{Cl}-\mathrm{SO}_{4}-$ $\mathrm{OH}-\mathrm{HCO}_{3}-\mathrm{CO}_{3}-\mathrm{CO}_{2}-\mathrm{H}_{2} \mathrm{O}$ system to high ionic strengths at $25^{\circ}$ C. Geochim Cosmochim Acta 48:723-751

Hedenquist JW, Henley RW (1985a) The importance of $\mathrm{CO}_{2}$ on freezing point measurements of fluid inclusions: evidence from active geothermal systems and implications for epithermal ore deposition. Econ Geol 80:1379-1406

Hedenquist JW, Henley RW (1985b) Hydrothermal eruptions in the Waiotapu geothermal system, New Zealand: their origin, associated breccias and relation to precious metal mineralization. Econ Geol 80:1640-1668

Hedenquist JW, Lowenstern JB (1994) The role of magmas in the formation of hydrothermal ore deposits. Nature 370:519-527

Helgeson HC, Kirkham DH (1974a) Theoretical prediction of the thermodynamic behavior of aqueous electrolytes at high pressures and temperatures: I. Summary of the thermodynamicelectrostatic properties of the solvent. Am J Sci 274:1089-1198

Helgeson HC, Kirkham DH (1974b) Theoretical prediction of the thermodynamic behavior of aqueous electrolytes at high pressures and temperatures: II. Debye-Hüeckel parameters for activity coefficients and relative partial molal properties. Am J Sci 274:1199-1261

Helgeson HC, Kirkham DH, Flowers GC (1981) Theoretical prediction of the thermodynamic behavior of aqueous electrolytes at high pressures and temperatures: calculation of activity coeffients, osmotic coeffients, and apparent molal and standard and relative partial molal properties to $600^{\circ} \mathrm{C}$ and $5 \mathrm{~kb}$. Am J Sci $281: 1249-1516$

Henjes-Kunst F, Kreuzer HM (1982) Isotopic dating of pre-Alpidic rocks from the Island of Ios, Cyclades, Greece. Contrib Mineral Petrol 80:245-253

Henley RW, Truesdell HA, Whitney JA, Barton PB Jr (1984) Fluidmineral equilibria in hydrothermal systems. Rev Econ Geol 1:267

Hubert AE, Chao TT (1985) Determination of gold, indium, tellurium, and thallium in the same sample digestion of geological materials by atomic-absorption spectrometry and two-step solvent extraction. Talanta 32:523-548

Johnson JW, Oelkers EH, Helgeson HC (1992) SUPCRT92: a software package for calculating the standard molal thermodynamic properties of minerals, gases, aqueous species and reactions from 1 to 5000 bars and $0^{\circ}$ to $1000^{\circ} \mathrm{C}$. Comp Geosci 18:899-947

Jolivet L, Faccenna C, Goffé B, Burov E, Agard P (2003) Subduction tectonics and exhumation of high-pressure metamorphic rocks in the Mediterranean orogens. Am J Sci 303:353-340

Jolivet L, Famin V, Mehl C, Parra T, Aubourg C, Hébert R, Philippot P (2004) Strain localization during crustal-scale boudinage to form extensional metamorphic domes in the Aegean Sea. In: Whitney DL, Teyssier C, Siddoway CS (eds) Gneiss domes in orogeny. Boulder, Colorado Geol Soc Amer Sp Pap vol. 380, pp 185-210

Kalogeropoulos SI, Kilias SP, Bitzios DC (1989) Genesis of the Olympias carbonate-hosted $\mathrm{Pb}-\mathrm{Zn}(\mathrm{Au}, \mathrm{Ag})$ sulfide ore deposit, eastern Chalkidiki peninsula, northern Greece. Econ Geol 84:1210-1234

Katzir Y, Matthews A, Garfunkel Z, Schliestedt M (1996) The tectono-metamorphic evolution of a dismembered ophiolite (Tinos, Cyclades, Greece). Geol Mag 133:237-254

Kelley KD, Romberger SB, Beaty DW, Pontius JA, Snee LW, Stein HJ, Thompson TB (1998) Geochemical and geochronological constraints on the genesis of Au-Te deposits at Cripple Creek, Colorado. Econ Geol 93:981-1012

Kilias SP, Kalogeropoulos SI, Konnerup-Madsen J (1996) Fluid inclusion evidence for the physicochemical conditions of sulfide deposition in the Olympias carbonate-hosted $\mathrm{Pb}-\mathrm{Zn}(\mathrm{Au}, \mathrm{Ag})$ sulfide ore deposit, E. Chalkidiki peninsula, N. Greece. Miner Depos 31:394-406
Mastrakas N (2007) Tinos granite and the associated skarn deposits. $\mathrm{PhD}$ Thesis, Univ. of Patras, p 240

Mastrakas N, St. Seymour K (2000) Geochemistry of Tinos granite: a window to the Miocene microplate tectonics of the Aegean region. N Jb Miner Abh 175:295-315

Meier AL, Grimes DJ, Ficklin WH (1994) Inductively coupled plasma mass spectrometry - A powerful analytical tool for mineral resource and environmental studies. US Geol Surv Circ 1103:67-68

Melidonis NG (1980) The geological structure and mineral deposits of Tinos Island (Cyclades, Greece): a preliminary study. IGME 13:1-80

Nebel ML, Hutchinson RW, Zartman RE (1991) Metamorphism and polygenesis of the Madem Lakkos polymetallic sulfide deposit, Chalkidiki, Greece. Econ Geol 86:81-105

Oakes CS, Bodnar RJ, Simonson JM (1990) The system NaCl$\mathrm{CaCl}_{2}-\mathrm{H}_{2} \mathrm{O}$ : I. The ice liquidus at $1 \mathrm{~atm}$ total pressure. Geochim Cosmochim Acta 54:603-610

Ohmoto H, Lasaga AC (1982) Kinetics of reactions between aqueous sulfates and sulfides in hydrothermal systems. Geochem Cosmochim Acta 46:1727-1745

Ohmoto H, Rye RO (1979) Isotopes of sulfur and carbon. In: Barnes HL (ed) Geochemistry of hydrothermal ore deposits. 2nd edn. New York, Wiley Interscience, pp 509-567

Okrusch M, Bröcker M (1990) Eclogites associated with high-grade blueschists, Cyclades Archipelago, Greece. Eur J Miner 2:451478

O’Neil JR, Taylor HP Jr (1972) Oxygen isotope fractionation between muscovite and water. J Geoph Res 74:6012-6022

O’Neil JR, Clayton RN, Mayeda T (1969) Oxygen isotope fractionation in divalent metal carbonates. J Chem Phys 51:5547-5558

Parra T, Vidal O, Jolivet L (2002) Relation between deformation and retrogression in blueschist metapelites of Tinos island (Greece) evidenced by chlorite-mica local equilibria. Lith 63:41-66

Patzak M, Okrusch M, Kreuzer H (1994) The Akrotiri unit on the Island of Tinos, Cyclades, Greece, witness to a lost terrane of Late Cretaceous age. N Jah Min Ab 194:211-218

Pulitz B, Matthews A, Valley JW (2000) Oxygen and hydrogen isotope study of high-pressure metagabbros and metabasalts (Cyclades, Greece): implications for the subduction of oceanic crust. Contr Min Petr 138:114-126

Richards JP, Kerrich R (1993) The Porgera gold mine, Papua New Guinea: magmatic hydrothermal to epithermal evolution of an alkalic-type precious metal deposit. Econ Geol 88:1017-1052

Roedder E (1984) Fluid inclusions. Rev Miner 12:550

Ronacher E, Richards JP, Reed MH, Bray CJ, Spooner ETC, Adams PD (2004) Characteristics and evolution of the hydrothermal fluid in the North Zone high-grade area, Porgera gold deposit, Papua New Guinea. Econ Geol 99:843-867

Scherbarth N, Spry GP (2006) Mineralogical, petrological, stable isotope and fluid inclusion characteristics of the Tuvatu gold-silver telluride deposit, Fiji. Comparisons with the Emperor deposit. Econ Geol 101:153-158

Shikazono N (1985) A comparison of temperatures estimated from the electrum-sphalerite-pyrite-argentite assemblage and filling temperatures of fluid inclusions from epithermal $\mathrm{Au}-\mathrm{Ag}$ vein type deposits in Japan. Econ Geol 80:1415-1424

Skarpelis N (2001) Geodynamics and evolution of the Miocene mineralization in the Cycladic-Pelagonian Belt, Hellenides. Bul Geol Soc Greece 35:2191-2206

Skarpelis N, Voudouris P, Arikas K (1999) Exploration for epithermal gold in SW Thrace, Greece: new target areas. In: Stanley et al (ed) Mineral deposits: processes to processing. Rotterdam, Balkema, pp 589-592

Stolz J, Engi M, Rickli M (1997) Tectonometamorphic evolution of SE Tinos, Cyclades, Greece. Schweiz Mineral Petrogr Mitt 77:209-231 
Suzuoki T, Epstein S (1976) Hydrogen isotope fractionation between OH-bearing minerals and water. Geochem Cosmochim Acta 40:1229-1240

Swartz SL, Seabaugh MM, Dawson WJ (1999) Nanostructured materials for electrochemical systems. Proc Electrochem Soc 99:13

Taggart JE Jr, Lindsey JR, Scott BA, Vivit DV, Bartel AJ Stewart KC (1987) Analysis of geological materials by wavelength-dispersive X-ray fluorescence spectrometry. US Geol Sur Prof Pap 1770:119

Taylor HP Jr (1974) The application of oxygen and hydrogen isotope studies to problems of hydrothermal alteration and ore deposition. Econ Geol 69:843-883

Thompson TB, Trippel AD, Dwelley PC (1985) Mineralized veins and breccias of the Cripple Creek district, Colorado. Econ Geol $80: 1669-1688$

Tombros FS (2001) The Au-Ag-Te polymetallic mineralization of Tinos Island, Cyclades, Aegean Sea, Hellas. PhD Thesis, Univ. of Patras, p 450

Tombros FS, St. Seymour K (1998) Applied geothermometry of the hydrothermal Au-Ag vein mineralization, Apigania. Bull Geol Soc Greece 32:165-172

Tombros FS, St. Seymour K (2003) Evolution of the hydrothermal fluid and explanation of the presence of cassiterite, at the polymetallic $\mathrm{Au}-\mathrm{Ag}$ mineralization of Apigania Bay, Tinos, Cyclades. Min Wealth 129:26-39

Tombros FS, St. Seymour K, Spry PG (2004) Description and conditions of formation of new unnamed $\mathrm{Ag}-\mathrm{Cu}$ and $\mathrm{Ag}-\mathrm{Cu}-\mathrm{Au}$ sulfotellurides in epithermal polymetallic $\mathrm{Ag}-\mathrm{Au}-\mathrm{Te}$ mineralization, Tinos Island, Hellas. Neues Jahrb Mineral Abh 179:295-310

Tombros FS, St. Seymour K, Williams-Jones A, Spry PG (2005) Greenockite and zincian greenockite in epithermal polymetallic $\mathrm{Ag}-\mathrm{Au}-\mathrm{Te}$ mineralization, Tinos Island, Hellas: description and conditions of formation. Neues Jahrb Mineral Abh 182:1-9
Tombros FS, St. Seymour K, Williams-Jones A, Spry PG (2007) The genesis of epithermal Au-Ag-Te mineralization, Panormos Bay, Tinos Island, Cyclades, Hellas (Greece). Econ Geol 102:

Vityk MO, Bodnar RJ (1995) Textural evolution of synthetic fluid inclusions in quartz during re-equilibration, with application to tectonic reconstruction. Contrib Mineral Petrol 121: 309-323

Vityk MO, Bodnar RJ, Schmidt C (1994) Fluid inclusions as tectonothermobarometers: relation between pressure-temperature history and re-equilibration morphology during crustal thickening. Geology 22:731-734

Voudouris P (2006) A comparative mineralogical study of Te-rich magmatic-hydrothermal systems in northeastern Greece. Mineral Petrol 87:241-275

Voudouris P, Alfieris D (2004) Ore mineralogy and evolution of Terich magmatic-hydrothermal systems in northeastern Greece. In: Cook NJ, Ciobanu CL (eds) Gold-silver telluride deposits of the Golden Quadrilateral, South Apuseni Mts., Romania: guidebook of the International Field Workshop of the IGCP Project 486, IAGOD Guidebook Series 12, pp 256-259

Voudouris P, Tarkian M, Arikas K (2006) Mineralogy of telluridebearing epithermal ores in Kassiteres-Sappes area, Western Thrace, Greece. Min Petr 87:31-52

Zeffren S, Avigad D, Heimann H, Gvirtzman Z (2005) Age resetting of hanging wall rocks above a low-angle detachment fault on Tinos Island (Aegean Sea): $\mathrm{K}-\mathrm{Ar},{ }^{40} \mathrm{Ar} /{ }^{39} \mathrm{Ar}$ geochronology and thermal modelling. Tectonophys 400:1-25

Zhang X, Frantz JD (1990) Determination of the homogenization temperatures and densities of supercritical fluids in the system $\mathrm{NaCl}-\mathrm{KCl}-\mathrm{CaCl}_{2}-\mathrm{H}_{2} \mathrm{O}$, using synthetic fluid inclusions. Chem Geol 64:335-350

Zhang X, Spry PG (1994) Calculated stability of aqueous tellurium species, calaverite, and hessite at elevated temperatures. Econ Geol 89:1152-1166 